\title{
DIÁRIO DA SEGUNDA VIAGEM DE BALDUINO RAMBO AO SUDOESTE DO RIO GRANDE DO SUL ${ }^{1}$
}

\author{
ARTHUR BLASIO RAMBO ${ }^{2}$
}

\section{RESUMO}

O Diário do grande botânico brasileiro Balduino Rambo relativo a sua segunda viagem ao sudoeste do Rio Grande do Sul é aqui publicado, pela primeira vez.

Palavras-chave: Balduíno Rambo, Fitogeografia, Rio Grande do Sul.

\section{ABSTRACT}

[The Diary of Balduino Rambo's second trip to southwest of Rio Grande do Sul State (Brazil)]. The Diary of the great Brazilian botanist Balduíno Rambo concerning to his second trip to southwest of Rio Grande do Sul State (Brazil) is published here for the first time.

Key words: Balduíno Rambo, Brazil, Phytogeography, Rio Grande do Sul State.

\section{INTRODUÇÃO}

O Pe. Balduíno Rambo começou a escrever o Diário pessoal aos 14 anos de idade, em 1919, e lançou o último registro em 11 de setembro de 1961, véspera de seu falecimento. O conjunto soma 49 volumes manuscritos, praticamente todos em alemão. Nos primeiros 20 anos serviu-se do sistema de estenografia "Stolze Schrei" modificado. Daí em diante costumou utilizar-se da escrita gótica "Süterlin". A parte em estenografia foi transcrita para letra corrente latina por seu colega, Pe. Antonio Steffen, e a parte em "gótico" pelo Pe. Arthur Rabuske.

O Diário cobre nada menos do que 40 anos, contendo registros e reflexões sobre o período de entre as duas Guerras Mundiais, sobre a Segunda Guerra Mundial e as transformações que o mundo sofreu a partir dela, na segunda metade da década de 1940 e ao longo da década de 1950.

O Pe. Rambo afirmava que o "Diário" era a “obra literária e científica da sua vida". De fato, nele se encontram inúmeras passagens que são peças literárias de grande beleza e inspiração, somadas a registros dignos da exatidão de um cientista e a reflexões sobre questões de nature-

Recebido em 10-5-2012 e aceito para publicação em 13-6-2012.

2 Professor Titular Emérito da UFRGS e da UNISINOS. Pesquisador do Memorial Jesuíta (UNISINOS, São Leopoldo - RS). Irmão de Balduíno Rambo. za social, filosófica e teológica. O que, porém, perpassa como um "Leitmotiv", de modo especial nos últimos 20 anos, é o amadurecimento gradual de uma cosmovisão que, senão de todo original, é pelo menos peculiar e orientada para a formulação de uma "Síntese" entre todos os campos do conhecimento: as Ciências Humanas, as Letras e Artes, as Ciências Naturais, a Filosofia e a Teologia. Devido a seu falecimento prematuro, aos 56 anos, ele não teve tempo para formular tal "Síntese". Os dados e as reflexões preliminares, todavia, se encontram dispersos pelo "Diário", principalmente a partir de 1944. Esse "Diário", como todo o restante do espólio científico e literário do Pe. Balduíno Rambo foi arquivisticamente organizado e microfilmado com financiamento do BNDES, e integra o acervo do Memorial Jesuíta da UNISINOS.

Nesta oportunidade, é oferecido ao público, pela primeira vez, o fragmento relativo à viagem realizada por Balduíno Rambo à fronteira oeste do Rio Grande do Sul entre 26 de dezembro de 1944 e 14 de janeiro de 1945 . Em grandes linhas, pode-se dizer que o texto trata de uma expedição científica que persegue o mesmo objetivo daquela de janeiro de $1941^{3}$ e, ao mesmo tempo, a complementa.

\footnotetext{
O texto da primeira viagem foi publicado nesta mesma revista (RAMBO, A.B. Viagem de Balduíno Rambo ao sudoeste do Rio Grande do Sul no ano de 1941. Balduinia, Santa Maria, n. 36, p. 13-29, 2012).
} 
Os cinco anos que separaram as duas saídas de campo ao sudoeste do Rio Grande do Sul deixam evidente algumas mudanças na maneira de proceder e pensar do Pe. Rambo. É verdade que continua intacta aquela apreciação que então fizemos sobre o perfil de cientista que ele foi. Mantém-se e, em termos, fica ainda mais claro que ele foi um sábio na investigação dos detalhes, mas sem nunca perder a perspectiva do todo. Para ele, os detalhes somente tinham sentido e mereciam atenção quando e enquanto vistos a partir do todo.

No presente texto transparece uma evolução na maneira pela qual o Pe. Rambo conduz a pesquisa. Como há cinco anos antes, ele continua a registrar suas observações sobre um pano de fundo, à maneira de um mapa descritivo ou de uma "fisionomia regional". Aparecem, entretanto, algumas diferenças significativas em relação à primeira viagem.

Em primeiro lugar, ela se deu no contexto de um acampamento de escoteiros, ao passo que na de 1941 ele viajou sozinho. Rambo mostrase perfeitamente à vontade acampado em companhia de rapazes, quase todos adolescentes, oriundos de famílias das classes média e alta de Porto Alegre. Ele os acompanha nas incursões pelo campo e se faz acompanhar de dois ou três deles para realizar as suas coletas. Entre esses quase meninos ele conquistou admiradores fiéis até hoje, cinqüenta anos depois de sua morte, como é o caso do Prof. Carlos Roberto Cirne Lima.

Em segundo lugar, os registros apontam um interesse quase tão grande pela Arqueologia indígena da região quanto pela Botânica. A razão, ao que me parece, deve ser procurada no fato de o Pe. Rambo ter sido nomeado, em 1942, catedrático fundador de Etnografia e Etnologia na então Universidade do Rio Grande do Sul, a atual UFRGS.

Em terceiro lugar, Rambo abandonou os registros extremamente exatos de datas, horários, tomada de fotografias e outros detalhes tão perceptíveis em seu diário de 1941.
Em quarto lugar, percebe-se uma crescente desilusão, para não dizer pessimismo, em relação ao futuro da herança cultural e lingüística dos imigrantes alemães no Brasil, resultante da guerra que começava a sinalizar uma vitória dos aliados, num horizonte não muito distante.

Resumindo: o Diário em foco retrata um Pe. Rambo bem mais amadurecido, de 41 anos de idade, somado a um bom saldo de experiências científicas e realizações, além do reconhecimento de suas conquistas por méritos pessoais. Sua fama de cientista, de mestre competente no Colégio Anchieta, de catedrático respeitado por seus pares e pelos alunos da Universidade, achava-se em franca ascenção.

Ao leitor, resta informar que as notas de rodapé foram elaboradas por Arthur Blasio Rambo (ABR), Fabiano da Silva Alves (FSA) e José Newton Cardoso Marchiori (JNCM).

\section{TEXTO DO DIÁRIO}

$$
\text { 26.12.1944 }
$$

Ida até a estação do trem - $10 \$ 000$

Guarda da mala $-43,900$

O dia é ameno. Os rapazes reúnem-se e estão bem dispostos ${ }^{4}$. Olhei para o campo. Por isso estou de baixo astral. O campo está seco e torrado. Não poucas vezes as fagulhas do trem incendiaram grandes extensões. Continuarão pretas e feias até a seguinte chuva. Mantenhome reservado. Aproveito a paisagem para refletir. Penso com íntima satisfação no meu povo. Volta-me à memória o tamanho da loucura daqueles que quiseram roubar-nos a nossa língua e a nossa maneira de ser. Não posso negar que a nossa identidade alemã encontra-se em suspenso entre nós. Ou fazemos da nossa terra uma terra

\footnotetext{
4 Os rapazes aqui em foco integravam a tropa de escoteiros "Manoel da Nóbrega", do Colégio Anchieta (Porto Alegre). O Pe. Rambo sentia prazer em acampar com esses jovens em meio à natureza virgem, o menos possível tocada pelo homem, motivo pelo qual ele participou de acampamentos de férias em Vila Oliva, Cambará do Sul, São Francisco de Paula e Quaraí, entre outros (ABR).
} 
de alemães ou partimos para uma outra que ainda é alemã ${ }^{5}$.

Não almoçamos no trem ${ }^{6}$. Os rapazes carregam um lote de coisas boas nas suas mochilas. O Pe. Pauquet ${ }^{7}$ manda trazer uma garrafa de cerveja. Pelas quatro horas chegamos a Santa Maria. Deixamos a bagagem mais pesada na estação. Alugamos um carro. Arrasta-se conosco pelas ruas. Primeiro propõe levar-nos por dois mil réis por pessoa até o seminário, em seguida desiste. Por fim fomos obrigados a fazer a mai-

5 Esta reflexão deve ser entendida no contexto histórico dos meses finais da Segunda Guerra Mundial. A vitória final dos Aliados, tanto na Europa quanto no Pacífico, era uma questão de tempo. O Pe. Rambo nunca deixou dúvidas sobre a fidelidade à sua identidade étnica e o amor à tradição, principalmente à língua alemã. Essa posição valeu-lhe não poucos dissabores, inclusive desconfianças de parte dos agentes da Campanha de Nacionalização e repreensões partidas de irmãos de Ordem, dos seus superiores religiosos, do Arcebispo D. João Becker e da cúpula da Cúria Metropolitana. É preciso não esquecer que a defesa das tradições e da língua como valor maior, somado à admiração pela Alemanha, nada tinham a ver com uma simpatia ou até concordância com o Nacional Socialismo. Tinha a ver, em primeiro lugar, com a sua preocupação para com os colonos de origem alemã no Brasil, pois se eles perdessem a identidade e, consequentemente, a sua índole, eles deixariam de ser um povo dotado de religiosidade à toda prova, de um convívio social e comunitário calcado na solidariedade, fundamentada em princípios éticos e morais inegociáveis. De outra parte, Rambo expressava abertamente a sua admiração pela cultura, valores, tradição e a terra de onde vieram os antepassados dos colonos do sul do Brasil, que continuavam a reconhecer a Alemanha como sua "velha pátria" (ABR).

6 Rambo quis dizer que não almoçaram no restaurante do trem (JNCM).

7 O Pe. Henrique Pauquet veio da Alemanha como jovem jesuíta na década de 1930, em consequiência do clima desfavorável à Ordem, criado pelo Nacional Socialismo. Concluiu sua formação religiosa em São Leopoldo e, depois, dedicou-se à juventude do Colégio Anchieta, por toda a vida. Homem de dinamismo fora do comum, ele pregou inúmeros retiros, construiu as Casas para a Juventude do Morro do Sabiá, ao sul de Porto Alegre, em Vila Oliva, no então município de Caxias do Sul, e comandou acampamentos de escoteiros do Colégio, como no presente caso. Sua obra maior foi a construção do Novo Colégio Anchieta, à avenida Nilo Peçanha, ao final da década de 1950 e começos de 1960. O Pe. Rambo e o Pe. Pauquet foram grandes amigos, embora de gênios quase opostos. or parte do trajeto a pé. Chegamos ao Seminário $^{8}$. O reitor recebe-nos na portaria. Apresentam-se, também, os padres Demmeler ${ }^{9}$ e Wecker $^{10}$. O Pe. Pauquet acomoda o seu povo. $\mathrm{O}$ Pe. Wecker acompanha-me para o meu quarto. Senta-se e quer informações sobre as mais diversas coisas, naturalmente sobre assuntos dos quais sei menos do que ele próprio. Explico-lhe que em Porto Alegre estamos num ponto morto do centro de informações. O Pe. reitor leva-me para o seu quarto e oferece-me um trago. Depois disso vou até a sala de leitura. Folheio o "Manual das Ciências Geográficas". Noto que esse livro ser-me-á de muito proveito. Preciso munir-me dele desde Quarai.

$\mathrm{O}$ Pe. Wecker não se aquenta e tenta levarme a uma conversa.

$\mathrm{Na}$ mesa, sentei-me ao lado do Pe. Middeldorf $^{11}$. A comida é muito melhor do que aquela que encontrei em outros lugares. O Pe.

8 Seminário Menor Diocesano São José, inaugurado por Dom Ático Eusébio da Rocha (28-2-1926), sob direção dos Padres da Companhia de Jesus. O edifício do seminário ficava em terrenos do atual Santuário da Medianeira, local quase suburbano, à época da viagem de Rambo (JNCM).

9 Pe. Gaspar Demmler S.J., jesuíta vinculado ao Seminário Menor Diocesano de Santa Maria e capelão do Santuário da Medianeira de 1948 a 1949 (RUBERT, 1957). Natural da Alemanha (1900), ele participou da Primeira Guerra Mundial como combatente. Mais tarde entrou na Companhia de Jesus e veio para o Brasil, onde atuou na formação de seminaristas em Santa Maria e na pastoral direta, em paróquias sob a responsabilidade da Ordem (ABR).

10 Nascido em Düsseldorf, Alemanha (1900), o Pe. João B. Wecker veio para o Brasil em 1937. Tinha doutorado em Ciências Sociais, mas nunca chegou a exercer o magistério por razões que não vem ao caso. Dedicouse à atividade pastoral em paróquias, hospitais e sanatórios. Em 1952 retornou à Alemanha, falecendo na Residência de Trier em 1986 (ABR).

11 Natural da Westfália, Alemanha (1873), o Pe. Germano Middeldorf veio definitivamente ao Brasil em 1909. Suas atividades resumiram-se na formação dos alunos do Colégio Conceição, Colégio Anchieta, Colégio Gonzaga e, de modo especial, dos seminaristas do Seminário Menor Diocesano São José, de Santa Maria, onde se encontrava na data em que o Pe. Rambo a ele se refere (ABR). 
Felisberto ${ }^{12}$ senta-se do meu lado e serve-se de feijão. Como foi possível que se aceitasse um homem desses na Companhia de Jesus? Para mim é uma charada insolúvel. Presumo que foi porque se pretendia contar, a qualquer preço, com "brasileiros" na província. A fisionomia do Pe. Kordt ${ }^{13}$ faz a gente doente. O homem tem a expressão de alguém que engoliu um agulheiro.

No recreio fiz um discurso incisivo em favor dos padres da velha guarda. O Pe. Middeldorf apoiou-me. Sirvo-me o tempo todo do alemão e, como de costume, num tom forte. No recreio desancando sobre tudo que está acontecendo no país. Aliás, estava bastante loquaz nesse recreio, provavelmente por efeito do cálice de bom vinho oferecido na mesa.

Fui dormir bastante cedo, mas não conseguia conciliar o sono. Apesar de baixar o mosquiteiro, os malditos sugadores de sangue penetravam e dificultavam-me o sono.

\subsubsection{4}

Dormi mal essa noite. Rezo a missa às cinco horas e trinta minutos, ajudado pelo irmão Lenz. Converso com ele durante o desjejum. O homem é muito bom e amigável. Disse-me que era o maior amigo do Pe. Hansen ${ }^{14}$. Chegou também o Pauquet. Theo Schröder ${ }^{15}$ queixou-se de

12 O Pe. Felisberto de Azevedo nasceu em Porto Alegre, em 1902. Estudou no Colégio Anchieta para depois entrar na Ordem como um dos primeiros jesuítas de origem luso-brasileira. Passou praticamente toda a vida em Santa Maria, dedicando-se por 33 anos à assistência religiosa de todas as classes sociais, de médicos a taxistas. Acompanha-o a fama de "Apóstolo de Santa Maria" (ABR).

13 O Pe Antônio Kordt foi outro jesuíta nascido na Alemanha e que veio trabalhar no Brasil a partir de 1939. Foi professor, bibliotecário, capelão de hospital e vigário cooperador de paróquia (ABR).

14 O Pe. Afonso Hansen nasceu em Linha Imperial (Nova Petrópolis, RS), foi colega de Seminário de Balduíno Rambo e seu amigo mais próximo, a quem confiou o seu "Diário" ou, como ele o chamava, "a obra literária e científica da minha vida". Mais tarde, o Pe. Hansen repassou o conjunto do Diário ao Pe. Arthur Rabuske, que providenciou sua transcrição, tradução e, em parte, a sua publicação (ABR).

15 Aluno do Colégio Anchieta (Porto Alegre), integrante do grupo de escoteiros (JNCM). dores de barriga. Às sete horas embarcamos no caminhão com o irmão Lenz que nos leva para a cidade ${ }^{16}$. Com algum esforço conseguimos lugar no vagão que vai até Alegrete.

Fumo meu charuto e aprecio a paisagem. Parece que a estiagem não é tão acentuada. Um pouco além de Santa Maria parece-me ter visto um fóssil ${ }^{17}$.

Ao meio dia paramos em Cacequi. Na plataforma encontramos o Pe. Steffen ${ }^{18}$. O homem é assustadoramente magro e envelhecido. Encontra-se de passagem, para pregar retiro na região.

O Pe. Pauquet acomoda-nos num hotel, na frente da estação. Acomodamo-nos num cômodo sem janelas e sem ventilação. A comida não foi grande coisa, a cerveja quente e o serviço mau.

Almoço e discretamente deixo o local. Acompanho o Pe. Steffen para uma garrafa de cerveja no restaurante da estação. Não demorou e o Pe. Pauquet fez-se presente, enquanto o Pe. Mascarello ${ }^{19}$ corre de um lado para outro.

A viagem até Alegrete é um tormento por causa da seca, do calor e do pó que sufoca. Olho pela janela e sinto uma grande vontade de cole-

16 O edifício do antigo Seminário, onde os viajantes pernoitaram, ficava em área praticamente suburbana na época. Demolido o edifício, o terreno deu lugar ao Parque e Santuário da Medianeira, local de peregrinação (Romaria da Medianeira) no segundo domingo de novembro (JNCM).

17 Troncos permineralizados, alguns de grandes dimensões, ainda hoje podem ser vistos em cortes da estradade-ferro, no trecho entre Santa Maria e Dilermando de Aguiar (JNCM).

18 Natural de São Luiz Gonzaga, o Pe. Antônio Steffen também foi colega de turma do Pe. Rambo. Foi professor de Filosofia e, nas férias, como usual entre os jesuítas que trabalhavam em colégios e outras instituições de ensino, pregava retiros. Foi o Pe. Steffen que revelou e transcreveu a parte do Diário do Pe. Rambo redigido em estenografia (ABR).

19 Jesuíta de origem italiana, o Pe. Cláudio Mascarello exercia o papel de capelão dos funcionários e operários responsáveis pela Viação Férrea do Rio Grande do Sul. Com domicílio em Santa Maria, o grande centro ferroviário da época, passava viajando por todo o Estado, prestando assistência religiosa aos dependentes da ferrovia (ABR). 
cionar na região ${ }^{20}$. Ela deve ser muito rica em espécies que eu ainda não conheço ${ }^{21}$.

Às quatro horas chegamos a Alegrete, cobertos de pó e sob o sol que queima. Reconquistamos lugar no trem e seguimos viagem. $\mathrm{O}$ calor do sol torna-se mais suportável. Até uma nuvem passa sobre o campo e caem algumas gotas de chuva. Pelas nove horas alcançamos

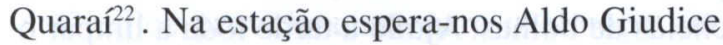
e seu filho ${ }^{23}$. Um motorista encomendado por ele carrega os nossos pertences. Giudice levanos até a igreja, onde combinamos com o Pe. $\mathrm{Bin}^{24}$ a missa para o dia seguinte. O Pe. Bin é um homem culto e de boa formação. Supõe-se muita coragem para agüentar num posto tão sem perspectivas. Num caminhão de carga vamos em companhia de Aldo até fora da cidade. Os rapazes $^{25}$ já estão acomodados num galpão. A comida fumega num panelão. Rezamos e sentamos à mesa. A comida é excelente. Os rapazes comem de dar medo.

20 Na viagem de 1941 ao sudoeste do Estado, Balduino Rambo registrou em seu diário a vontade de "retornar" à região do Cerro do Tigre (município de Alegrete) para coletas botânicas (RAMBO, 2012, p. 23).

${ }_{21}$ O "faro" do botânico não falha: se ele houvesse coletado naquela oportunidade, certamente diversas espécies endêmicas dos morrotes e campos de areia teriam sido por ele descritas para a ciência, com anos de antecedência. Viajando de trem, restava lastimar tal impossibilidade (JNCM).

22 Cidade e município do Rio Grande do Sul, situado na fronteira com a República Oriental do Uruguai, frente a Artigas, da qual se separa pelo rio Quaraí (JNCM).

23 Engenheiro, político e estancieiro, Aldo Pereira Giudice nasceu em Quaraí (24-5-1900), filho do coronel Olímpio Giudice e de Josefina Pereira Giudice. Com curso superior realizado na Itália, foi prefeito de Quaraí em duas oportunidades: eleito em 1935, renunciou em 1937, por ocasião do Estado Novo, mas foi reconduzido ao cargo em 1956. Faleceu em Quaraí a 3-6-1986, “coberto pela admiração de sua terra e sua gente", de acordo com MARÇAL (1995). O filho a que Balduíno Rambo ser refere era João Carlos Pereira Giudice, aluno do Colégio Anchieta, que se encontrava em férias em Quaraí (JNCM).

24 Vigário de Quaraí desde 10 de janeiro de 1935, o Pe. Quirino Bin foi transferido em 16 de maio de 1945 para a paróquia de Santiago, passados poucos meses, portanto, deste encontro com Rambo (JNCM).

25 Integrantes da tropa de escoteiros (ABR).
Depois da janta sentamo-nos lá fora, ao ar livre, para decidir o que faríamos no dia seguinte. Foi combinado que o acampamento seria instalado não nas proximidades do $\mathrm{Jarau}^{26}$, mas no Quaraí Mirim ${ }^{27}$, porque lá há mais mato e água.

O dono da casa mandara aprontar para nós dois duas camas na sala grande da casa que fora um antigo matadouro. Pauquet dorme no canto e eu junto à porta. Demora um bom tempo até que consigo dormir. Mal fecho os olhos, o galo empoleirado no galpão dos rapazes começa a cantar. Pulgas também se fazem presentes, provavelmente também percevejos. Finalmente, contudo, consegui adormecer.

\subsubsection{4}

Acordo pelas cinco horas da manhã. Tiro o Pauquet da cama. Serrou tábuas ${ }^{28}$ a noite inteira, mas afirma que não dormiu ou quase não dormiu nada.

O automóvel leva-nos até a cidade. Rezo a missa por primeiro. Rüdiger ${ }^{29}$ e João Giudice ${ }^{30}$ fizeram de ajudantes. Presente está uma meia dúzia de mulheres e mais ninguém. Depois da

${ }^{26}$ Cerro do município de Quaraí, cenário de uma das mais conhecidas lendas do Rio Grande do Sul: A Salamanca do Jarau, incluída por João Simões Lopes Neto em sua obra "Lendas do Sul". A palavra deriva, provavelmente, de "y'iara", a senhora das águas; de "y", água, "iara" ou "yara", dono, dona, proprietário, senhor: mulher fantástica, sereia de rios ou lagos na mitologia indígena; e "y, água, rio; significando rio das y'iaras (FURTADO, 1969). A respeito da origem do nome derivar de "Yaros", antigo grupo indígena, a hipótese pode ser refutada, pois o grande Félix de Azara informa que no tempo da conquista estes índios habitavam a costa oriental do rio Uruguai, entre os rios Negro e San Salvador, tendo por vizinhos, a leste, os Charruas, e a norte os Bohanes e Chanás. Azara acrescenta que os Yaros "deviam ser valentes, pois atacaram e mataram um número muito considerável de espanhóis que acompanhavam o capitão Juan Alvarez, primeiro navegante do Uruguai. AZARA (1968). Por fim, agrega que os Yaros “(...) foram exterminados pelos Charruas" (FSA e JNCM).

27 Afluente da margem direita do rio Quaraí, com foz a jusante da cidade de mesmo nome (JNCM).

28 Serrar tábuas significa roncar toda a noite (ABR).

${ }^{29}$ O Rüdiger era o chefe da tropa de escoteiros (ABR).

30 João Carlos Olímpio Giudice, filho de Aldo Giudice e estudante do Colégio Anchieta (Porto Alegre), na época (JNCM). 
missa voltamos até o galpão. Os rapazes já estão em pé. Tomamos café. $\mathrm{O}$ carro deveria ter chegado. O caminhão de carga com os nossos pertences não demora em chegar, mas Giudice se fez esperar. Pelas oito horas decidimos movimentar-nos com os rapazes e a viatura disponível. Pauquet seguiria em companhia de Giudice.

Partimos. O carro cruza o campo seco e desolado. O Jarau acena de longe ${ }^{31}$. Passamos por um bom número de leitos de arroios secos. Em parte nenhuma, sinal de água. Todo o campo está seco e torrado. Depois de uma viagem de uma hora chegamos ao Quaraí Mirim ${ }^{32}$. A água está muito baixa. Não demorou e avistei um bom número de espécies novas ${ }^{33}$. O Aldo alcançounos naquele ponto. A viagem continua pelo campo seco. Descemos até o rio. Paramos e passamos pelas moitas até o arroio que vem do $\mathrm{Jarau}^{34}$. O lugar, porém, não nos agrada. Descemos até a beira do mato. Descemos até o ponto onde o arroio entra no Quaraí Mirim ${ }^{35}$. Um magnífico lugar. Água em abundância. O rio forma uma bacia larga e funda. $\mathrm{O}$ arroio cai marulhando por uma pequena cascata com água potável. Descarregamos na beira do mato ${ }^{36}$. O plano original foi levantar o acampamento no campo aberto. Depois de algumas considerações, decidimos transferi-lo para dentro do mato, na margem do rio. Vou até o arroio ${ }^{37}$ e faço a barba. Depois tomo um banho. Na margem do

31 No Planalto da Campanha, o conjunto de cerros do Jarau se destaca na paisagem, sobretudo para quem sai da cidade de Quaraí em direção norte, caso de Balduíno Rambo naquela oportunidade (JNCM).

32 Afluente da margem direita do rio Quaraí, no município de mesmo nome (JNCM).

33 Novas para a coleção do autor, mas não, necessariamente, para a ciência botânica (JNCM).

34 Trata-se da sanga Nhanduvaí, que mais adiante figura, repetidas vezes, pelo nome equivocado de Nanduti (JNCM).

35 Rambo refere-se à foz da sanga Nhanduvaí no Quaraí Mirim (JNCM).

$36 \mathrm{O}$ acampamento foi montado à margem esquerda da sanga Nhanduvaí, junto à sua foz no Quaraí Mirim. O local exato pode ser buscado no Google Earth pelas seguintes coordenadas: $30^{\circ} 15^{\prime} 28.07^{\prime \prime} \mathrm{S}, 56^{\circ} 32^{\prime} 09.54^{\prime \prime}$ $\mathrm{O}(\mathrm{JNCM})$. rio entrei perigosamente num pântano. Bem junto à água coleto e acomodo uma série de espécies.

Um peão do Aldo preparou o almoço. Foi excelente. Seguiu a instalação do acampamento. Acho melhor não coletar hoje. Empunho o facão e abro caminho que deve levar até o acampamento. Não demorou e estou com as mãos cheias de bolhas. Ajudo a tarde toda a limpar o lugar do acampamento. Os rapazes são em geral um tanto desajeitados. Admiro o Rüdiger, jeitoso e empenhado no trabalho. Uma barraca depois da outra é levantada. Junto ao rio, no triângulo formado pela desembocadura, ergue-se um telheiro estreito, atrás uma barraca comprida e logo do lado uma barraca com formato de casa. Mais adiante, uma grande lona formando um telhado. Junto à desembocadura ergue-se a grande barraca que Giudice conseguira junto ao comandante da guarnição de Quaraí. Anexo a este, uma pequena barraca de soldado e, por fim, a barraca de Aldo Giudice. E para completar, um pequeno telheiro.

À noite, um peão de Giudice veio com duas camas, com colchão e travesseiro, uma para mim e outra para Pauquet. Como podem ver, moramos bem acomodados aqui no mato. Instalo minha cama na grande barraca militar, pensada para servir de capela nos dias de chuva. Com essas ocupações passa a tarde. Pelo fim da tarde chega Giudice. Sua mãe ${ }^{38}$ estava de visita na estância. Manda um saco de coisas para os rapazes.

Estamos, felizmente, bem instalados. Tenho uma fome como poucas vezes. Vamos dormir cedo à noite. Durmo como um toco.

$$
\text { 29.12.1944 }
$$

O canto dos jacus e o tagarelar das garças acordam-me pelas cinco horas. Tiro Pauquet da cama e vou até o rio lavar-me e instalo o altar. Rezo a primeira missa aqui na mata virgem do Quaraí.

\footnotetext{
37 Sanga Nhanduvaí, como explicado em nota anterior (FSA).

38 Josefina Pereira Giudice (JNCM).
} 
São nove horas quando estamos prontos. Reúno minhas coisas e subo a montante do rio, beirando o mato. $\mathrm{O}$ calor da manhã é bem suportável. Encontrei com facilidade um bom número de espécies novas. É uma pena que o campo esteja tão seco. Circulo a manhã inteira pela beira do mato. Volto ao meio dia com um considerável número de espécies novas.

Giudice providenciara para o almoço um churrasco de ovelha. A carne é muito gorda, mas devoro uma quantidade considerável. Acontece que aqui no mato tudo cai bem.

Logo depois do almoço desempacoto minhas coisas e ponho a secar ao sol, sobre a areia do arroio, as plantas coletadas de manhã. Passo para o outro lado do arroio $^{39}$ para examinar a outra margem. Circulei a tarde toda pelo local, ora pelo mato, ora perto do rio, ora no campo seco. Carrego comigo um belo número de espécies novas.

Todo o tempo que estou aqui mantenho uma parte da atenção para possíveis sítios de instrumentos dos índios ${ }^{40}$. Ao anoitecer, topo inesperadamente, na descida de um barranco, com a metade de uma flecha de pedra. Com isso atiçase em mim a atenção. Começo a procurar. Não demora e encontro espalhados no capim um considerável número de lascas mais menos grosseiras. Recolho-as e as junto num monte. Não demorou, encontro um local pedregoso, com dezenas de lascas espalhadas. Tenho a impressão de encontrar-me num sitio científico importante. Junto uma porção de lascas, mas levo apenas algumas peças comigo, já que tenho dificuldade de carregá-las no bolso.

Depois caminho pelo campo. Constato que a pedra utilizada pelos selvagens é arenito cozido: arenito vermelho e cozido. Um banco dessa pedra, de apenas dois metros de largura, estende-se por dois quilômetros pelo campo. Em toda a parte onde aflora, encontram-se, em quantidade, aquelas lascas. Na superfície, a pedra está

39 Para a margem direita da sanga do Nhanduvaí, a oeste da mesma (JNCM).

40 Não custa lembrar que o Pe. Balduíno Rambo era professor de Etnografia e Etnologia na Universidade do Rio Grande do Sul (atual UFRGS) desde 1942 (JNCM). literalmente descascada.

Infelizmente não encontrei uma única peça inteiramente acabada. Trata-se na maioria de peças semi-acabadas. Na maioria dos casos a matéria prima foi apenas minerada. Ao que parece os pedaços não foram trabalhados até o fim. É possível que o acabamento tenha sido dado em outro local. As lascas seriam então as sobras. Enchi os bolsos com lascas. Encontrei, em casa, caras bastantes céticas. Só poucos entendem que é possível fazer alguma coisa de útil com essas pedras. Para mim não há dúvida de que se trata de instrumentos. Tenho a suspeita de estar em contato com o período mais antigo. Desde os tempos mais remotos quase não se fizeram progressos essenciais.

Custei a dormir esta noite. Encontro-me num sítio $^{41}$ que promete muito.

De noite é servida uma sopa e uma excelente carne, mandada pelo senhor Giudice. Esta noite ele fica conosco.

À noite os rapazes acendem o fogo do conselho. Assisti pela primeira vez ao cerimonial. Enormes chamas sobem por entre as copas das árvores. Fico sentado perto e deixo o fogo aquecer-me e lembro-me, tomado de melancolia, que essa também é uma herança e um hábito germânico. Os rapazes procuram cantar alguma canção, mas tudo fica muito sem graça. Acontece que na língua portuguesa não se conhecem verdadeiras canções populares. Nós, alemães, temos um tesouro em cantos, que também pretendem tomar-nos. Não os entregaremos, os velhos e amados cantos.

Pelo final da reunião retiro-me para rezar. A água marulha suavemente sobre a areia e a rocha. A flor branca floresce nos ângulos mortos. A lua surge pálida e brilhante por de trás do mato. Deito-me de costas e contemplo as estrelas lá no alto.

Os rapazes vão pescar. O banho alvoroçoume, ao ponto de não conseguir dormir por um bom tempo. Talvez seja, também, porque andei o dia inteiro ao sol quente.

\footnotetext{
41 Sítio arqueológico (FSA).
} 


\subsubsection{4}

Levanto às cinco e quarenta e cinco e, às seis, rezo a missa. Depois vou até a barraca da cozinha e tomo dois copos de leite fresco e como três fatias de pão preto. Enquanto os rapazes assistem à missa, vou até o arroio. Pretendo colecionar hoje o maior número de exemplares possível. Em primeiro lugar, decidi avaliar a extensão da oficina de pedras que descobri ontem. $\mathrm{O}$ banco de arenito começa logo depois do arroio. A pequena cascata no arroio é formada pela continuação do banco. Bem perto do matinho topo com as primeiras lascas. Observo verdadeiros montes delas. Escolho as melhores e as guardo na bolsa que levei para essa finalidade. $\mathrm{O}$ banco parece esgalhar-se e desdobrarse em diversas direções. Em cada ponto onde observo encontro lascas em abundância. É o caso especialmente num determinado local, onde a rocha aflora numa superfície maior. Recolho no mínimo dois quilos de lascas. Também desta vez, infelizmente, não encontrei nenhuma peça inteira.

Volto ao campo. O sol queima impiedosamente na nuca. Tenho a suspeita de que aqui na clareira deve ter havido um paradeiro dos selvagens. Mas por mais que procuro não encontro nenhum vestígio. Em todo lugar onde o capim deixa o chão à vista encontro lascas em quantidade. Prova que este lugar foi habitado e abrigou por muito tempo uma população numerosa. Chego em casa pelo meio dia, cansado e esfomeado, mas com uma sacola pesada, cheia de artefatos de pedra.

Saio novamente logo depois do meio dia. Para começar, caminhei ao longo do arroio. $\mathrm{O}$ sol queima como fogo. Já que perto do arroio havia pouca coisa, enveredei pelo campo seco e desolador, em direção ao Jarau. Não pretendi ir propriamente até o morro. Em toda a parte as ovelhas descansam na sombra das poucas árvores dispersas no campo ${ }^{42}$. Na minha aproximação, elas fogem campo afora.

42 Neste campo de solo arenoso, percorrido por Rambo, as únicas arvoretas que ali se encontram são espinilhos (Vachellia caven (Molina) Seigler \& Ebinger) e
Caminho até bem próximo ao morro ${ }^{43}$. Poderia continuar até ele, mas não tem muito sentido, pois teria que retornar em seguida. Decido acompanhar um banco de arenito, ao longo do qual há evidências da presença humana por toda a parte. Também aqui encontro lascas em quantidade. Desço até o arroio. Encontrei até um pântano. Bem no meio cresce um bosque que não consigo alcançar ${ }^{44}$. Acompanho o arroio. Em toda a parte o banco de arenito cruza o leito do arroio. Profundos buracos de redemoinho foram nele escavados. Encontro algumas plantas, mas o resultado é pequeno e muito abaixo da expectativa. $\mathrm{O}$ arroio largo, cobreando pelo campo, faz um belo conjunto com o morro. Um quadro de paz e natureza intocada.

$\mathrm{O}$ sol queima. Tomo água do arroio. Encontro um bom número de lascas, em bom estado. Concluo que toda a região está tomada pelas lascas. Aqui aguarda um espólio como não existe outro no estado. Chego em casa cansado e moído ${ }^{45}$. Ao anoitecer tomo banho. Os rapazes vão pescar. Estou cansado e durmo logo.

inhanduvás (Prosopis affinis Spreng.). No texto do Diário brilha a ausência de qualquer menção a estas duas espécies chaquenhas, motivo de confusão terminológica em toda a obra do autor; sobre este ponto, recomenda-se a leitura de MARCHIORI \& ALVES (2010). Resta informar que Balduíno Rambo realizou, de fato, uma coleta de inhanduvá na Fazenda do Jarau: trata-se da exsicata $\mathrm{n}^{\circ} 26.354$ (in campestribus siccis), conservada no Herbário PACA (UNISINOS, São Leopoldo). Em 11-8-1954, Emrich \& Rambo identificaram este material como Prosopis algarobilla Gris. var. ñandubay (Lor. ap. Gris.) Hassl.; sabe-se, hoje, entretanto, que se trata de Prosopis affinis Spreng. (JNCM).

43 Balduíno Rambo refere-se ao Cerro do Jarau (JNCM).

44 Nestas matinhas paludosas dominam: a capororoca-dobanhado (Myrsine lorentziana (Mez) Arechav.), a laranjeira-do-banhado (Citronella gongonha (Mart.) R. A. Howard), o sarandi (Cephalanthus glabratus (Spreng.) K. Schum.), a corticeira-do-banhado (Erythrina cristagalli L.), a embira (Daphnopsis racemosa Griseb.) e o caraguatá-do-banhado (Eryngium mesopotamicum Pedersen), entre outras espécies (FSA e JNCM).

45 Pudera: Rambo deve ter caminhado pelo campo, ao sol quente, pelo menos $18 \mathrm{~km}$ neste dia (JNCM). 


\subsubsection{4 - domingo}

Acordo só depois da seis horas. A noite é de mormaço e quente. Pesadas nuvens cobrem o céu. Lavo-me no arroio. O Pe. Pauquet reza a primeira missa. Em seguida subo o altar. Durante a missa o vento é tão forte que temo que a árvore encostada no altar o derrube. Faço uma breve alocução. Pelo fim da missa ouvem-se trovões surdos ao longe. Tomamos café na minha barraca. A chuva começa mansa. Mas o vento a espanta. Só pelo meio dia começa uma chuva mais forte. Troveja ao longe o tempo todo, mas não resulta numa chuva mais significativa.

Acondicionei pela manhã as plantas secas. A maioria está seca. Embrulho em papel as amostras de ferramentas de pedra e as acomodo numa pilha. São mais de cem exemplares. Estou orgulhoso pelo resultado. Quanto mais avalio essas peças, tanto mais cresce em mim o desejo de vasculhar para valer toda a região. Depois redijo o diário. Tomamos o almoço de novo na minha barraca. A chuva está no ponto mais forte. Deito-me por uma hora. Enquanto escrevo estas linhas a chuva já cessou. Pretendo dar hoje à tarde ainda uma circulada pelo campo.

Depois do meio dia a chuva cessou por completo. Apronto a minha sacola de couro e vou campo adentro. Desta vez na frente do mato por onde passa a estrada. Encontro mais material ainda do que na outra margem do arroio. Também aqui não há peças acabadas. Encho a sacola. De qualquer forma, uma boa colheita.

Ao voltar, encontro o capataz da fazenda. Contou que soube pelo rádio que os alemães avançavam pela Bélgica. Teriam abatido muitos aviões inimigos. Churchill fora quase apedrejado em Atenas. Lá ele empossou um novo governo. Os japoneses sofreram derrotas. Infelizmente, o homem não tem informações suficientes para dar notícias garantidas. Tenho a impressão que as coisas andam bem.

Vou barbear-me e, para tanto, preciso ir até $\mathrm{o}$ arroio. A chuva impede-me. De noite jantamos apertados na minha barraca. O Laux ${ }^{46}$ pre-

46 Integrante da tropa de escoteiros, o Laux era o encarregado da cozinha naquele dia (ABR). parou apenas 52 batatas para 16 pessoas. Isso valeu-lhe um trenzinho ${ }^{47}$ em regra. Para encerrar o dia rezamos o rosário, mas a conversa foi até tarde da noite. Por fim adormeço.

\subsubsection{5 - segunda-feira}

Às cinco horas tocou o despertador do Pe. Pauquet. Infelizmente os jacus não cantam mais. Depois que dois foram caçados, os outros preferem ficar em silêncio. Levanto pouco antes das seis. Encontrei o Pe. Pauquet em roupa de ginástica, junto à cascata, praguejando por ter perdido há mais dias a escova de dentes.

Apronto o altar e paramento-me. Demora a começar a missa. Os rapazes vão tarde para cama e de manhã custam a sair das penas. A missa começa pelas sete horas. Rezo-a pelos meus entes queridos. Depois da missa rezo a metade do breviário. Neste meio tempo ouço a aproximação do carro do Dr. Aldo. Pegamos os nossos pertences e subimos. Encontramos o carro pequeno e o de carga. Embarcamos e partimos.

Encontramos um senhor de idade que parecia ser um italiano. $\mathrm{Na}$ frente da casa alinhavam-se quatro fileiras de "Melien"48. A idosa dama $^{49}$, de aniversário, recebe-nos na porta da casa. Erguemos o altar no canto do avarandado. Os rapazes postam-se no corredor. O Pe. Pauquet faz o sermão. Comete erros de linguagem, mas de resto fala bem.

Terminada a missa aproximo-me dos rapazes. O Dr. ${ }^{50}$ presenteou-me com 12 instrumentos de pedra, a maioria bolas de boleadeiras. Significa um belo enriquecimento para minha já respeitável coleção. Enquanto o Pe. Pauquet toma café, caminho com os rapazes pelo campo. Por toda a parte aflora o arenito. Trata-se,

47 Forma de castigo, o "trenzinho" consiste em fazer o faltoso passar, de quatro, entre as pernas abertas dos companheiros enfileirados, levando, de cada um, uma boa palmada no "pólo sul" (ABR).

48 Cinamomos ou paraísos (Melia azedarach L., Meliaceae), árvore exótica muito cultivada em todo o Rio Grande do Sul (JNCM).

49 Dona Josefina Pereira Giudice, mãe do Dr. Aldo (JNCM).

${ }^{50}$ Aldo Pereira Giudice, proprietário da estância (JNCM). 
porém, de uma pedra mole, de grãos soltos, impróprio para ferramentas.

Voltamos. Aldo mandara encilhar os cavalos. Os rapazes cavalgam pelo campo. Tivemos um enorme trabalho para convencê-los de manter firmes os arreios. Aldo presenteia-me com 12 bolas que ele colecionara com tempo pelo campo $^{51}$. Representam um belo reforço para a minha coleção.

Reunimo-nos junto ao transmissor para ouvir notícias. Aldo sintoniza a Rádio Belgrano ${ }^{52}$, mas não resulta em nada. Ao meio dia acomodamo-nos na mesa debaixo das "Melien". Primeiro serve-se maionese, depois macarrão, finalmente vem o churrasco. Tomo um cálice de vinho. Os rapazes comem que é um espanto. O pequeno Pedro Couto, com uma enorme costela entre os dentes, mastiga e mastiga até não poder mais. Por fim serviu-se ainda de sobremesa, toma um gole de cerveja e declarou que estava todo duro. Levanta-se depois e caminha para cá e para lá, com as mãos nos quadris.

Não se pode negar que foi um excelente almoço. As senhoras de idade serviram-se tagarelando numa pequena mesa colocada no centro. Aldo oferece-me um charuto de muito boa qualidade.

Depois do almoço vou com quatro ou cinco rapazes em busca de plantas. Acompanhamos o curso da água, onde encontrei um bom número de espécies. Cai em vista a configuração do córrego que conflui mais adiante com aquele na qual se encontra a estância. É muito estreito e fundo, parecendo ter sido escavado no arenito. Ao chegarmos à extremidade superior do leito, Aldo e os demais vêm descendo o morro.

O valo é conhecido desde tempos antigos como Sanga das Contas, pois aqui no ponto mais estreito e mais fundo foram encontradas nume-

51 Provável repetição do informado no parágrafo anterior, pois é pouco provável que o Dr. Aldo tenha presenteado 12 peças arqueológicas a Rambo em duas oportunidades, no mesmo dia (JNCMi).

52 De Buenos Aires. As rádios argentinas eram muito ouvidas em todo o Rio Grande do Sul naquela época, sobretudo na região da fronteira (JNCM). rosas contas de vidro. Desço com três rapazes até o fundo, entro até os joelhos na água fria e remexo a areia. Lidamos mais de meia hora, sem encontrar nem pista de pérolas. Um pouco adiante se encontra um ponto ainda mais estreito e mais fundo. Não é possível chegar até lá porque a água é muito funda. Por isso desisto.

Volto até a estância. Os rapazes sentam-se num semicírculo diante das damas e cantam. $\mathrm{O}$ esbelto Galgo deita-se no centro do semicírculo e dorme. O canto não é ruim. Olhando para os rapazes veio-me à memória o dito: "imorredoura beleza. Numa ponta vai morrendo corporal e espiritualmente. Na outra continua crescendo indefinidamente". Vem-me à memória, também, a pobreza em cultura. $\mathrm{O}$ brasileiro não dispõe de autênticas canções populares. Contudo, não posso negar de todo o valor de toda aquela apresentação.

Pelas cinco horas pusemo-nos a caminho. $\mathrm{O}$ anoitecer anuncia-se por sobre o campo. A chuva, que pingou o dia inteiro, cessa lentamente. Lá longe, no campo, avisto uma ovelha preta. Diz o nosso acompanhante negro que é preta provavelmente porque nasceu no dia 24 de janeiro. Pergunto o motivo e ele respondeu por que ele próprio nasceu no dia 24 de janeiro e é preto. É um sujeito magnífico. Seu nome verdadeiro é Francisco dos Santos. Há pouco tempo veio uma carta de Caxias para Quaraí. Apenas com seu apelido e a cidade de Quaraí. E a carta chegou sem problema. Conhece uma série de histórias. Ele afirma, com os pés juntos, que a fábula da cobra que mama na vaca é verdadeira. Ele mesmo nunca viu pessoalmente. Soube dele que as fêmeas das emas põem os ovos em ninho comum e o macho choca ${ }^{53}$. Mais tarde acompanhou os rapazes. Afirmou, ainda, que o jacaré choca os ovos com os olhos. Ao retornar encontrei minha barraca no chão. $\mathrm{O}$

\footnotetext{
53 A respeito dos costumes, superstições e lendas sobre a avifauna brasileira e sulamericana, recomenda-se a obra de um contemporâneo de Rambo (TESCHAUER, 1925), que foi padre jesuíta e importante historiador (JNCM).
} 
vento forte a derrubou. Felizmente nada foi estragado. Vamos dormir cedo.

\subsubsection{5 - terça-feira}

A noite inteira soprou vento forte. Em certos momentos transformou-se num verdadeiro tufão, a ponto de temer por minha barraca. Ao amanhecer, a temperatura baixou a ponto de duas cobertas não serem suficientes para aquecer. A queda brusca de temperatura é fora do comum. Batendo os dentes, vou até o rio para me lavar. Depois da missa fico em dúvida se é conveniente ir até o Jarau naquele dia. A temperatura é amena e a paisagem ensolarada. A caminhada não seria cansativa. Como, porém, o Pe. Pauquet havia comentado que talvez fossemos de carro durante a semana, desisti. Reúno minhas coisas e subo pela margem do rio pelo campo. A chuva parece ter influído pouco sobre o crescimento das plantas. O campo está seco como antes. Cá e lá recolho uma ponta de flecha e desço quase até o passo, onde passamos o rio na vinda para cá. Encontrei um bom número de coisas, até um ninho de ema, que estava abandonado. Em volta, haviam muitas cascas de ovo. Ao meio dia estou de volta.

Depois do meio dia cruzo o arroio e atravesso o mato de espinhos ${ }^{54}$. Não há muito que buscar no local. De nenhuma excursão reuni tão pouco material quanto aqui. Também os instrumentos indígenas são poucos. Sigo até o segundo arroio que desemboca junto com o Nanduti ${ }^{55}$ no rio Quaraí. Tenho plena certeza de que o ponto central dos instrumentos indígenas encontra-se em ambas as margens do Nanduti. Entende-se e tem a sua explicação. Aqui os selvagens gozavam da proteção dos dois cursos de água

${ }^{54}$ As matas ciliares da região são margeadas por uma savana com espinilhos (Vachellia caven (Molina) Siegler \& Ebinger) e outras plantas espinhosas. Resulta curioso que Balduíno Rambo nunca tenha atribuído o nome de "espinilho" à referida espécie botânica. Aqui, também, a palavra é atribuída à vegetação em seu conjunto: mato de espinhos ou espinillal, como dito pelos vizinhos castelhanos (JNCM).

55 Erro de transcrição; trata-se, evidentemente, da sanga Nhanduvaí (JNCM). por ambos os lados. O rio, abundante em peixes, e o mato, rico em caça, eram um grande atrativo. Quanto mais a gente se afasta do centro de irradiação, isto é, o triângulo formado pela desembocadura do arroio, tanto mais raros se tornam os achados.

Todos os achados indicam técnicas de confecção muito rudimentares. Tenho a convicção de que procuro em vão instrumentos melhor acabados. A maioria das peças deve ser vista como pontas de flecha. Mas não há certeza sobre isso em muitas delas. Merecem ser classificadas na categoria de pontas de lança. Outras são demasiado pesadas e grosseiras. Quem sabe trata-se de raspadores, cavadores, perfuradores, machados de punho. De resto, todo esse material causa-me cada vez mais a impressão de semelhança com instrumentos paleolíticos. Pela primeira vez começo a pensar na possibilidade de que aqui se trata de uma cultura que não tem nada a ver com os charruas, mas pertencente a um estágio anterior. Empolgo-me cada vez mais com a idéia.

À noite há fogo de conselho e a recepção de seis rapazes no círculo dos escoteiros. A cerimônia é simples e singela. Os seis rapazes, José e Jorge Lara, Flávio Zanini, Theo Schrader e José Giudice apresentam-se iluminados pelas chamas. Os demais estão sentados em semicírculo, com as pernas cruzadas. Pfaff chama um por um para diante da bandeira. Com a mão estendida prometem fidelidade aos estatutos da federação. Em seguida o padrinho entrega-lhes o chapéu. Por meio de um aperto de mão teatral, o padrinho e o chefe confirmam o ato. Por fim, o Pe. Pauquet dá a bênção a cada um.

Depois o Pe. Pauquet fez um pronunciamento breve mas sólido: o chapéu do escoteiro deverá ser o oposto do chapéu da Rua da Praia. Não é nem no cinema, nem no baile que o rapaz se faz homem, nas na pureza, no rigor dos costumes e na seriedade. $\mathrm{O}$ brilho das chamas emoldura as silhuetas das figuras jovens. Eu experimentaria uma sincera alegria em tais coisas, se não me minasse sem parar a dor pela destruição da minha língua e do meu povo. $\mathrm{O}$ homem é o pior 
carrasco do homem. Exatamente por causa dessa perseguição, por causa dessa imperdoável agressão à liberdade dos outros homens, posiciono-me em favor dessa feroz defesa da minha liberdade, da minha maneira de ser, da minha língua. É por isso que devolvo com agressividade o ataque de quem ousa tocar, mesmo de leve, a minha liberdade.

\subsubsection{5 - quarta-feira}

Ontem à noite combinei com o Flávio Zanini de que hoje iríamos até o Jarau. A noite foi novamente tão fria que tive de recorrer a dois cobertores. Rezei a missa às seis horas, ajudado pelo Zanini. Depois, tomamos alguns copos de leite, comemos alguma coisa, levamos algumas provisões e uma garrafa de campanha com chocolate e partimos.

A clara manhã sorria sobre o campo. No céu navegavam as brilhantes nuvens de vento norte, anunciando a virada do tempo. Avançamos com vontade. Depois de mais uma hora de marcha escutamos um grito na margem do banhado. Parecia que alguém estivesse vomitando. Olhei naquela direção e avistei um cachorro do mato parado na encosta da elevação, olhando em nossa direção. Depois de algum tempo parado correu um trecho, parou, gritou e foi embora. De vez em quando deixou que nos aproximássemos bastante. Por fim, saiu correndo como um cachorro flagrado numa malandragem. $\mathrm{Su}$ miu na encosta da elevação. Por algum tempo escutamos ainda o seu grito no campo ${ }^{56}$. Chegamos ao lugar onde se encontram as fontes da sanga Nanduti ${ }^{57}$. Em todos os valos flui água e no banhado cresce capim e juncos enfeitados por um belo verde.

A cumeada parecia fugir de nós. As distâncias enganam muito. Depois de cada seqüência de elevações surge outra. Finamente chegamos a um local onde em tempos idos deve ter havi-

56 Vivenciamos esta mesma experiência no Cerro do Jarau em 2010, por ocasião de coletas botânicas (JNCM e FSA).

57 Sanga Nhanduvaí, em verdade (JNCM). do uma estância ${ }^{58}$, pois há um grande pomar de laranjeiras carregadas com frutos maduros. Logo além passamos por mais dois valos com água potável.

Deitamos na sombra ao pé do morro. Até aqui levamos duas horas. Eu tinha avaliado a distância em torno de uma hora e meia. Pergunto ao Flávio quais os planos para o ano seguinte. Responde-me com singeleza que iria para o Kappesberg $^{59}$. Fernando Englert vai a Pareci e um certo Nunes entraria também na Ordem.

Subimos o morro. A encosta está toda coberta com pedras soltas ${ }^{60}$. Entre elas crescem muitas plantas que me parecem espécies novas. Mas o dia inteiro não encontrei vestígios da presença de indígenas. Confirma-se a minha suspeita de que os selvagens não ocupavam o topo do Jarau, mas as redondezas, ao longo do rio Garupá e Quaraí-Mirim. Acontece que o dorso despido do morro não oferecia muito atrativo. Os rios ofereciam peixes e os matos, em volta, abundância de caça. Do alto, a vista espraia-se sobre a planície. Ao longe ${ }^{61}$, se avista Quaraí e Artigas. No outro lado ${ }^{62}$ avista-se um arroio que, à primeira vista, julguei ser o Quaraí. Na verdade é o Garupá ${ }^{63}$. Neste lado, o morro desce suavemente até a planície. Um belo mato acompanha um arroio que corre em direção ao Garupá. Aqui, no alto, as rochas são de arenito

58 Ruínas da estância de Bento Manoel Ribeiro (JNCM).

59 Nome popular e original do município de Salvador do Sul, então distrito do município de Montenegro. Em Kappesberg se encontrava a "Escola Apostólica", instituição de grau médio, para a formação dos futuros jesuítas. Quem lá estudava em regime de internato alimentava, em princípio, a intenção de entrar na Ordem dos Jesuítas depois de completado o grau médio. Dos dois rapazes mencionados, Fernando Englert, de conhecida família de Porto Alegre, entrou na Companhia de Jesus, mas saiu da Ordem durante a formação (ABR).

${ }^{60}$ Descrição fidedigna, irretocável (JNCM).

${ }^{61}$ Em direção sudeste (JNCM).

${ }^{62}$ Ao norte (JNCM).

${ }^{63}$ Arroio, afluente do rio Quaraí, que serve de divisa entre os municípios de Quaraí e Uruguaiana. O arroio Garupá contorna os cerros do Jarau pelo lado norte, descrevendo um semi-arco nesta região (FSA). 
fortemente cozido $^{64}$. Por vezes, as camadas caem a pique.

Caminhamos para o outro lado e seguimos pelo flanco até alcançar o ponto mais alto, onde se encontra o marco indicando a altura. A trilha é miserável e pedregosa. Apesar disso, encontro sempre novas plantas. Sempre perseguidos pelas mutucas, valendo-nos de dois caminhos encantadores, alcançamos o ponto mais alto, com o marco que registra uma altura de 183 metros $^{65}$. Não é muito. Decidimos descer também pelo outro lado. Entre as rochas encontrei uma palma que me parecia digna de nota ${ }^{66}$. Infelizmente extraviei os brotos que colhi ${ }^{67}$. A descida do morro é sobremodo difícil. O capim alto encobre de todo as inúmeras pedras roliças que cobrem todo o chão. A cada passo o pé escorrega para uma outra direção.

Encaminhamo-nos para uma galeria de mato onde esperamos encontrar água, mas fomos decepcionados. O valo está completamente seco.

${ }^{64} \mathrm{Na}$ viagem de 1941, ao ver de longe o Jarau, Rambo especulou que sua composição fosse de basalto (RAMBO, 2012, p. 24).

${ }_{65} \mathrm{O}$ ponto culminante do Jarau tem $308 \mathrm{~m}$ de altitude (ALVES, 2012, p. 49).

66 Descrição perfeita: tendo vindo do sul, Rambo encontrou os exemplares de Butia lallemantii no flanco norte do Cerro do Jarau, no exato local onde ainda hoje se encontram os poucos exemplares da espécie na região (JNCM).

67 Destes agrupamentos de palmeiras, Balduíno Rambo preparou a exsicata 26.090, conservada no Herbário PACA (UNISINOS, São Leopoldo). A etiqueta informa que a coleta foi realizada em janeiro de 1945 na "Fazenda do Jarau". Em 5-9-1954, este material foi identificado como Butia bonneti (Linden) Becc., por Emrich \& Rambo. Sem ter conhecido a população in loco, Larry Noblick também se equivocou ao atribuir a referida exsicata a Butia paraguayensis (Barb. Rodr.) L.H. Bailey, em 22-5-1992. A identidade destas palmeiras somente foi esclarecida por ALVES \& MARCHIORI (2010): trata-se de Butia lallemantii Deble \& Marchiori, espécie típica dos campos de areia do sudoeste gaúcho e que tem seu limite ocidental de distribuição geográfica no topo do Cerro do Jarau. Cumpre notar que ambas as espécies se assemelham quando examinadas em herbário; Butia lallemantii, todavia, é palmeira de hábito cespitoso, ao passo que Butia paraguayensis distingue-se facilmente na natureza por ter estipe único (JNCM e FSA).
Só muito mais adiante topamos com a primeira água. Somos obrigados a continuar ainda por uma boa distância até encontrar água corrente, muito fresca e gostosa. Deitamos na sombra e comemos o nosso farnel, tomamos chocolate e conversamos sobre isso e aquilo.

Enchemos os cantis com a água cristalina do mato e, acompanhando o Garupá, costeamos o morro. Na verdade deveríamos passar pelo topo, mas lá cresce um mato selvagem de moitas. Numa depressão cruzamos o morro e, acompanhando o Quaraí ${ }^{6}$, ladeamos o morro. A encosta está toda coberta de pedras que tornam o caminhar muito difícil. Finalmente avistamos o último e mais regular dos morros de arenito. Superando a confusão de blocos caídos conquistamos o alto.

A caverna não é grande coisa. Uma entrada bastante regular, de mais de três metros de altura e quatro de largura, abre a entrada de um recinto de dois e meio metros de profundidade. À esquerda, uma fenda estreita leva até o topo do morro. À direita, em cima, a fenda entra abrupta para dentro do morro. Infelizmente não temos lanterna conosco. Os morcegos fazem-se ouvir na escuridão. $\mathrm{O}$ chão e as pedras estão cobertas com os dejetos dos morcegos e percebe-se o odor forte de guano.

A caverna formou-se a partir do desabamento da parte frontal do rochedo. Podem-se observar as fendas nos dois lados, preenchidas com material moído.

Sentamo-nos por algum tempo. Fumo um charuto. Coleto uma samambaia que cresce dentro da caverna. Tiro uma foto. Entretanto já são duas e meia e pusemo-nos a caminho de volta. Enveredamos em diagonal pelo campo, em direção ao arroio. Passamos ainda vários cursos de água com água potável.

A marcha torna-se cada vez mais pesada e cansativa. Sem dizer uma palavra caminhamos lado a lado. O embotamento da marcha faz-se sentir. Às cinco e meia estamos em casa. Estou cansado como um toco. Estou tão cansado que

${ }^{68}$ Equívoco: trata-se do Garupá (JNCM). 
nem sequer tomo banho. Caio na cama e, apesar do barulho, adormeço imediatamente ${ }^{69}$.

\subsubsection{5 - quinta-feira}

$\mathrm{O}$ cansaço de ontem foi-se quase de todo. Só os pés ainda doem. Rezo missa às seis horas, depois ponho-me a caminho. Caminho pelo campo até o portão pelo qual entramos. Encontro uma série de plantas novas ${ }^{70}$, faço uma foto do velho ninho das emas e, pelo meio dia, chego cansado em casa. Tento dormir um pouco depois do meio dia, mas não dá em nada. É muito quente. Os rapazes entram sem parar na minha bodega e fazem barulho no recipiente com água. Pego as minhas plantas e acondiciono o que está na prensa e numero tudo como deve ser. Gasto um bom tempo com isso. Pelas quatro horas os rapazes vão passear. Vou com eles até o campo, perto do mato e procuro pontas de flecha. Encontro peças em boas condições, embora nada de especial.

À noite o Dr. Aldo está conosco. Tomamos chimarrão, sentados em volta do fogo. Cantamse algumas canções. O Dr. Aldo acompanha um canto espanhol cantado por seu filho. Depois

69 Pudera: a caminhada de Rambo pelo campo, neste dia, foi de mais de $27 \mathrm{~km}$, distância percorrida que não é para qualquer pessoa; é preciso muita resistência física (JNCM).

${ }^{70}$ É bem possível que a coleta $\mathrm{n}^{\circ} 26.144$ de Mimosa ramboi tenha sido realizada neste dia. Espécie nova, o material foi publicado por Arturo Burkart no ano seguinte (1946), com o epíteto específico que presta homenagem ao botânico gaúcho. A respeito da localidade típica, o leguminólogo argentino esclarece que ela se encontra cerca de "100 metros da mata ciliar do rio Quaraí Mirim, no vértice formado por este rio e a sanga do Nhandubay" (BURKART, 1946, p. 229). Trata-se, justamente, do sítio percorrido por Balduíno Rambo neste dia, no início da jornada. A respeito desta coleta, RAMBO (1966, p. 41) agrega que a espécie-tipo procede da Fazenda do Jarau, em campo pedregoso com gramíneas (in campestribus saxosis graminosis). No Herbário PACA existe uma outra exsicata da mesma espécie: a de $\mathrm{n}^{\circ} 32812$, coletada por Aldo Pereira Giudice em dezembro de 1945, provavelmente a pedido de Rambo. Ao cotejar ambas as exsicatas, chama atenção que a coletada por Rambo (janeiro de 1945) tenha flores e a coletada por A.P. Giudice (dezembro de 1945) tenha frutos semievolutos (FSA e JNCM). ele próprio canta algumas canções napolitanas. Chamou-me a atenção que todos os cantos são em outra língua, ou em espanhol ou em italiano. Essa realidade demonstra toda a pobreza da língua portuguesa em cantos populares.

Tomo ligeiro um banho. A sessão prolongouse além do comum. Finalmente os rapazes entregam-se a trovas.

João Braga e Saturno participam, mas não se deixam convencer para cantar alguma coisa. Finalmente o Pe. Pauquet encerra o encontro. Acho que, de fato, estava acabado. Estou redondamente enganado. O Pe. Pauquet resolveu renovar a água. $\mathrm{O}$ recipiente é esvaziado com muito ruído e novamente enchido com um vai vem a pé, em meio a uma correria sem fim no acampamento. Aldo e mais alguns estão pescando. Levanto um pouco a lona e observo como Laux caça besouros. Com certa dureza mandeio para a cama. Pauquet ronca como uma serraria. O calor é grande. São quase doze horas ${ }^{71}$ quando consigo adormecer.

\subsubsection{5 - Sexta-feira}

De manhã cedo atravessei o rio até a outra margem. Um caminho bem largo leva ao campo. O campo está tão seco e desolado como aqui. Em alguns pontos aflora a mesma pedra da qual os selvagens confeccionaram seus instrumentos. Os vestígios de sua presença são muito raros. Encontro apenas algumas pontas. Em compensação topo com uma boleadeira em forma de lentilha, muito bem acabada, a primeira que encontrei. Caminho ainda um bom tempo pelo campo. O sol queima como fogo e sinto muita sede. Vou até o rio e coleto sobre as rochas uma grande quantidade de pedras de potassa (Pottstein).

Para o almoço oferece-se um churrasco muito bom. Não se pode negar aos "brasileiros", eles sabem assar a carne. Acompanha um pirão com carne. Depois, durante uma hora, tomo chimarrão com o Aldo. Contou-me que seu avô imigrara para o Brasil em 1835. Era oriundo de

\footnotetext{
71 Meia noite (JNCM).
} 
Sapar, no sul da Itália, enquanto sua mãe era natural da Riviera. O avô juntou-se a Garibaldi e participou de todo o levante. Depois viajou pelo Estado todo como viajante comercial e amealhou uma grande fortuna. Aldo passou dois anos na Itália, em 1922, para formar-se em técnica. Até foi buscar a bênção do papa. Disse que o vigário de Quaraí tinha pouca formação. Era um bom homem e era tudo.

Paira uma sombra sobre o homem. Somente no dia seguinte o Pe. Pauquet pôs-me a par. Não se entende com a mulher. Ela é natural de Montevidéu. Não se interessa pelo campo. Ele prefere viver no campo. Por isso ela passa a maior parte do ano em Porto Alegre, enquanto ele vai raras vezes até lá. Aqui em Quaraí ele se fez acompanhar com outra mulher. Acompanhao sempre nas pescarias. A coisa avançou ao ponto de os dois pensarem em separação. O rapaz provavelmente não sabe de nada. A filha mais velha parece estar a par de tudo. Pauquet tem razão quando diz: "Tudo começa com a malversação do casamento, continua com o divórcio e no final termina com a ruína da família". Na Campanha, a família está a caminho da total dissolução. É raro encontrar-se uma família sadia com mais filhos. Com mais de dois são uma exceção. Se esse povo continua nessa direção está fadado ao desaparecimento. A nós, basta perseverar um pouco ainda na preservação da nossa maneira de ser, da nossa língua. Os "brasileiros" liquidam-se por eles mesmos.

Há pouco tempo atrás tentaram eleger Aldo como prefeito de Quaraí. Já o foi no passado. Mas quando exigiram que se comprometesse com o Estado Novo, recusou. O povo todo se mantém fiel, com muita firmeza, a Flores da Cunha.

Durante a tarde caminhei pelo mato nas proximidades do acampamento e coletei um bom número de espécies ${ }^{72}$. Quanto mais entro em

72 Dentre as espécies mais características, citam-se: o coqueiro-gerivá (Syagrus romanzoffiana), o guabiju (Myrcianthes pungens), o araçá-do-mato (Myrcianthes cisplatensis), o angico-vermelho (Parapiptadenia contato com esse mato, tanto mais espécies nele descubro. No campo encontrei um bom número de pontas. Minha coleção não para de crescer. Tenho a impressão que essa coleção tem mais valor do que as plantas que reúno.

Hoje o calor foi muito grande. Para a minha satisfação vamos dormir cedo de noite. Não demoro em adormecer.

\subsubsection{5 - Sábado}

Como de costume, rezo a missa às seis horas. Como três biscoitos e tomo duas xícaras de leite. Quando estava para sair disseram-me que os rapazes fariam também uma excursão. Escutei que um grupo pretendia ir até a desembocadura do Quaraí. Decido acompanhá-los. Comunico minha decisão ao pessoal e combino esperálos no outro lado do arroio. Trabalhei durante uma boa hora e com um bom resultado. Meu pessoal não apareceu. Começo a pensar que mudaram de idéia. Escuto então um assobio e gritos vindos do acampamento. Pouco depois escuto chamados no outro lado. Grito, mas não tenho resposta. Pensando bem, prefiro assim. Suo como um desgraçado e as mutucas atormentam-me para valer. Coleciono até as dez horas e vou para casa. Encontro o Pe. Pauquet sozinho no banho. Acomodo-me no barranco e fumo um charuto e observo o Pe. Pauquet. Visto o calção de banho e a camisa, pego o bote de inflar e vou coletar. Coleciono [ ...] e outras plantas no barranco. Depois nado para valer. O banho fazme um bem até a alma.

Termino o breviário. Com isso é meio dia. Pergunto ao Pauquet o que havia para o almo-

rigida), o açoita-cavalo (Luehea divaricata), a guajuvira (Cordia americana), o camboatá-branco (Matayba elaeagnoides), o camboatá-vermelho (Cupania vernalis), a canela-preta (Nectandra megapotamica), o coentrilho (Zanthoxylum fagara), o tarumã-de-espinhos (Citharexylum montevidense), a figueira-mata-pau (Ficus lushnathiana), o pessegueiro-do-mato (Prunus myrtifolia), o branquilho-leiteiro (Sebastiania commersoniana), a murta (Blepharocalyx salicifolius), duas capororocas (Myrsine laetevirens, Myrsine lorentziana) e dois marmeleiros (Ruprechtia laxiflora, Ruprechtia salicifolia) (FSA e JNCM). 
ço. Responde que ainda não estava pronto, mas que não demoraria. Vou com ele até a cozinha. O convite para a mesa começa com a ordem de buscar água. Depois preparo a mesa. Na dispensa encontro um pedaço de queijo duro como uma pedra. Bananas e biscoitos completaram o cardápio. Não posso afirmar que estava ruim. Depois do almoço acomodo-me na minha barraca e tiro as plantas das prensas. Constato que o material coletado na quarta-feira, no Jarau, secou bem. Depois acomodo o que colecionei ontem e hoje. Com isso já passa das três horas. Apanho o equipamento de coletar e vou ao campo. Encontro um pequeno cactus todo enterrado no chão ${ }^{73}$. Apenas a flor amarela sobressai. Ouço os gritos dos rapazes. Evidentemente não foram até a desembocadura do Quarai. Estava muito quente.

Ando pelo campo e o mato até às cinco horas e coleto um bom número de espécies. Depois tomo banho. O tempo está quente e muito seco. O vento é morno e sufocante. Se não chover, em breve, o campo seca e morre.

\subsubsection{5 - Domingo}

Ontem de noite eu tinha programado ir hoje em busca dos restos de Gliptodonte que Rüdiger tinha encontrado. Mas Laux achou que os rapazes estavam muito cansados. Melhor seria se dormissem até às oito horas. Levantei às cinco horas e trinta minutos e aprontei o altar. Às seis horas tirei Pauquet da cama. Rosnava e gemia. Engraçado, de manhã evita qualquer ruído para não perturbar os rapazes, enquanto de noite ele próprio promove o maior dos teatros. Rezo o breviário. Pauquet desaparece com toalha e sabão na direção da cascata. Quando chego nas "completas" ele reaparece e ajuda-me a missa. Tomo duas xícaras de leite quente, como três biscoitos e vou para a estrada. Quero encontrar sozinho o ponto em que Rüdiger achou fragmento da couraça do Gliptodonte. Passo pelo mato. Num determinado ponto alguns jacus le-

73 Trata-se, muito provavelmente, de uma espécie de Frailea (JNCM). vantam vôo. Logo depois um animal maior pula de um tronco baixo e desaparece no mato. Infelizmente não deu tempo para identificá-lo. Parecia de cor marrom e imaginei que fosse um puma. Não seria impossível. Senti-me um tanto apreensivo. Seguro firme a faca e continuo. Cruzo o rio num ponto mais estreito. Julguei que fosse o lugar onde Rüdiger encontrou os restos, mas nada encontro. Mais tarde Rüdiger afirma que não era esse o lugar. Volto devagar pela outra margem do rio. Coleto mais uma série de espécies. Chego ao acampamento ao meio dia, cansado e com fome. Depois do meio dia acondiciono em primeiro lugar as plantas. Constato que todo material coletado anteontem está seco. São agora três horas. Depois caminho pelo mato ao longo do rio e coleciono mais algumas espécies.

Enquanto isso impõe-se em mim, com crescente força, a convicção de rejeitar qualquer influência daqueles que se conjuraram para roubar-me a germanidade. Cheguei a um ponto em que considero de antemão imoral e mal vinda qualquer influência que quiserem exercer sobre mim. Há uma interminável hipocrisia, tanto na ascese, quanto na maneira como se faz valer a autoridade entre nós. Por isso enclausuro-me no meu mais íntimo santuário. A ele nenhum mortal tem acesso, nem os superiores. Chego em casa cansado e suado.

$$
\text { 08.01.1945 - segunda -feira }
$$

A partida para o Jarau foi fixada para as seis horas. Meu despertador tocou às quatro horas e dez minutos. Levantei e fui lavar-me no arroio e aprontei o altar. Ajudaram Zanini ${ }^{74}$, Carlos Roberto Cirne Lima ${ }^{75}$ e Flores. O último tinha

\footnotetext{
74 Zanini deixou a Ordem durante a formação e graduouse em Direito (ABR).

75 Filho de Rui Cirne Lima, professor de Direito na UFRGS e um dos juristas mais conceituados de sua época, Carlos Roberto Cirne Lima entrou na Ordem dos Jesuítas e fez doutorado em Filosofia e Teologia na Alemanha e Áustria. Mais tarde, saiu da Ordem e foi professor na UFRGS. Depois de aposentado, foi professor de Filosofia na UNISINOS. Renomado especialista em Hegel, Cirne Lima vive em Porto Alegre e é um dos maiores admiradores do Pe. Balduíno Rambo (ABR).
} 
a incumbência de iluminar-me com a lanterna de bolso. Foi um momento solene quando levantei a hóstia consagrada em direção às estrelas.

Como tinha previsto, a partida arrastou-se por um bom tempo. Já tinha passado das seis horas quando o povo saiu das barracas. Depois de finalmente terminada a missa e o Dr. Aldo chegado, alguém derrubou a água do café e houve um considerável atraso. Finalmente o café ficou pronto. Também o João fez-se presente. Entregou duas belas pontas de pedra belamente lascadas dos dois lados.

Pouco antes das oito horas tudo estava acomodado dentro do pequeno carro de carga e no grande, puxado por três cavalos. No nosso carro viajam Aldo, Pauquet, Carlos Cirne Lima, o pequeno Giudice e alguns outros. Antes de mais nada andamos no caminho normal até a estância. Lá foi preciso reparar alguma coisa no carro. A velha dama recebeu-nos muito amigavelmente. Mandou-nos uma cesta com uvas. Trabalha no local um italiano, senhor com mais de 70 anos, de nome Francisco Fontana. Já trabalhou para o pai de Aldo. Estávamos reunidos com o Dr. Aldo. Declarou ser brasileiro, mas depois do Brasil vinha a Itália. Ele achava um mau sinal quando alguém não amava a terra de origem. Isso me fez muito bem, pois, presente estava um bom número de jovens. Partimos somente pelas dez horas. Saturno cavalgava na frente para indicar o caminho.

Passamos pelo local onde antigamente se encontrava a casa de Bento Manoel Ribeiro ${ }^{76}$. Apenas um único muro ficou como testemunha da antiga grandeza. As pedras foram utilizadas para construir uma pequena casa na qual mora um guarda. Na frente da casa estende-se um grande pátio e uma cerca de restos de pedra.

76 Natural de Sorocaba (São Paulo), Bento Manoel Ribeiro fez rápida carreira militar nas lutas do Prata. General durante a Revolução Farroupilha, serviu mais tempo ao Império do que à República de Piratini. Considerado traidor, por muitos, dele se dizia, na época: "Todos merecem perdão, só o Bento Manoel que não". Faleceu em Porto Alegre, em 1855 (JNCM e FSA).
Sobre essa paisagem pesa a atmosfera dos séculos. Neste local reuniam-se os farrapos para fazer do Brasil uma República. Descemos um pouco o morro até chegar ao arroio. Deixamos o carro e fomos procurar um lugar para o acampamento no mato. Sem demora o encontramos. Desempacoto minhas coisas e vou para o campo, acompanhado por Cirne Lima. Encontro um grande número de plantas. Encontramos um ninho de perdigão, com dois ovos cor de chocolate. Neste meio tempo, os demais subiram até o topo do morro, onde se encontra o marco da altura. Carlos Roberto sobe e eu vou para o acampamento. Toda a bagagem estava aí reunida. $\mathrm{O}$ Dr. Aldo descansava na sua cama de campanha. Nos últimos dias tornou-se ainda mais sério e mais silencioso. A situação com a mulher aparentemente força para uma decisão. Tenho pena do homem. Tem um bom coração e sabe tudo que a mulher aprontou. Tenho uma fome de cão. Devoro uma quantidade inacreditável de churrasco, hoje especialmente bem preparado. Um peão, jovem louro parecendo um alemão, preparou-o. Ele mora lá em cima, na pequena casa. Mas Aldo informou-me que era um italiano. Tem uma mulher baixinha e trabalhadora, 15 filhos, entre eles um rapaz que já ajuda no trabalho. Comparo esse homem simples e pobre com o Aldo. Este tem dinheiro em abundância, mas uma vida familiar desastrada. O peão, pelo contrário, um bando de crianças queridas e uma mulher trabalhadora e amada. Depois do almoço subo em companhia de Zanini e Carlos Cirne Lima até o topo do marco de altura. Encontramos Saturno fazendo sinais com um espelho. O calor do sol é insuportável. Encontro um grande número de espécies. Caminhamos pelo morro e cruzamos pela encosta para alcançar a parte dianteira. Também lá colho um considerável número. Examinamos a Sanga das Contas. O que lá se encontra consiste num banco de meláfiro decomposto. Uma fenda de até cinco metros de profundidade, em alguns pontos de apenas um metro de largura, corta o campo. Essas fendas extraordinariamente estreitas e profundas não parecem ser raras aqui no campo. 
Tínhamos combinado que iríamos nos encontrar na fenda às quatro horas, com o Aldo e os demais. Mas o pessoal não apareceu. Escutei tiros ao longe, mas não vi ninguém. Decidi não esperar ninguém para acompanhar-me na coleta.

O senhor louro emprestou-me um cobertor para a noite. Não quis aceitar, mas ele insistiu e não tive escolha. Estendi-a sobre o chão e desdobrei as duas outras por cima, empurrei a prensa com as plantas debaixo do travesseiro e deitei-me para dormir. Comecei deitando com a roupa. As estrelas espreitavam por entre os galhos. A chuva, que parecia inevitável uma hora antes, tinha sumido. Acordei pela meia noite. Percebi um prurido estranho no corpo. Parecia que o colchão tinha inquilinos. Tirei a roupa e dormi até de manhã. Esta é a primeira vez, depois de 17 anos, que durmo ao relento.

\subsubsection{5 - terça-feira}

Levantei às cinco e meia, fui lavar-me no arroio e aprontei o altar. Zanini e Carlos Cirne Lima ajudaram-me na missa. A partir do evangelho também os outros assistiram à missa. $\mathrm{O}$ Dr. Aldo não se fez presente. O Pe. Pauquet rezou a missa mais tarde. Depois preparamos o café. Rezei uma boa parte do breviário. Depois do café soube que todo o grupo pretendia ir até a caverna. Pego minhas coisas e caminho na frente. O sol está mais quente do que nunca. Ando durante uma hora, para cá e para lá, na frente do morro. Escutei então a algazarra da rapaziada e observei o gado correndo pelo campo. Associo-me aos rapazes, mas não demorou e fiquei para trás, retido cá e lá por plantas. De longe enxerguei os rapazes na caverna. Recebem-me com um fogo na entrada da caverna e matam morcegos. Dois ou três subiram por dentro, mas não estavam no fim e só encontraram dejetos de morcego. Subi até o topo do morro. Coleto várias plantas e faço fotos. Daqui de cima percebe-se claramente que toda a seqüência de elevações é formada por arenito cozido e trabalhado pelas intempéries. Em alguns pontos as camadas são perpendiculares. A superfície da rocha está fortemente decomposta. O morro como um todo dá a impressão de uma ruína. Pelas dez horas tiro uma foto na entrada da caverna, quando caí feio entre as pedras. Depois partimos. Tenho uma sede de cão. No arroio bebo um capacete cheio de água.

Faminto e com sede chego em casa pela uma hora acompanhado por Luis Reis. O almoço parece não estar pronto. Termino então o breviário. Almoçamos suflê com massa e carne. Como uma quantidade enorme. Pauquet procura-me para encarregar-me de uma tarefa muito incômoda, escrever uma matéria para o jornal de Quaraí. Depois me coage para benzer o cemitério da velha estância. Vou até o cemitério, rodeado por uma taipa rústica de pedra. Há pouco fora roçado. Uma enorme figueira ${ }^{77}$ cresce à esquerda da entrada. As raízes forçam o grande jazigo, construído à maneira brasileira. Em cima encontra-se um epitáfio quebrado, com inscrição em espanhol. A sepultura está aberta. Sobre ele, espalhados, veem-se tábuas bem conservadas de um caixão, inclusive restos de um tecido preto. Não observo ossos e mais tarde soube que nesse túmulo foram sepultados os pais da mãe de Aldo. Mais tarde, os restos mortais foram transladados para Quaraí. Outra sepultura está muito mais danificada. Schinus molle ${ }^{78}$ e outros arbustos tomaram conta. Mais de quinze a vinte cruzes de ferro, com inscrições espanholas apagadas e sem vestígio de sepultura cobrem a superfície do terreno. Abençoei o cemitério com uma simples benção sacerdotal.

Caminho, depois, sob o sol escaldante até o banhado e coleto ainda um belo número de espécies. Pelas três horas estou de volta. Todos estão empenhados em acondicionar as bagagens e as carregam até o carro. Estava previsto que partiríamos às quatro horas, mas os cavalos não tinham chegado. Partimos, finalmente, pelas quatro e meia. Tomamos o mesmo caminho da

77 Ficus lushnathiana (Miq.) Miq. (Moraceae), espécie nativa na região (JNCM).

78 Nome científico da anacauíta, aroeira-salso ou aroeiraperiquita, Anacardiácea de ampla dispersão no Rio Grande do Sul (JNCM). 
vinda. Na estância, a velha senhora presenteounos com uvas. Bastos e Pedro Couto tiveram ligações telefônicas com Porto Alegre. O pequeno Carlos berrava para dentro do fone fazendo tremer os caibros. Entendia-se muito pouco. Às seis horas estamos em casa. Tudo em ordem. Estou exausto e tomo banho. À noite foi servido café, biscoitos, roscas e uvas.

Vou dormir antes da reza do terço. Os rapazes rezam o terço na beira do rio. Adormeço em meio à algazarra. Poucas vezes senti-me tão cansado.

\subsubsection{5 - quarta-feira}

Dormi bem na noite que passou, apesar da zoeira dos rapazes. Pela meia noite acordei com a sensação de uma enorme canseira nos ossos, mas adormeci de novo. Acordei pelas cinco horas com uma sensação de cansaço. Apesar disso, salto da cama pontualmente às cinco e meia. Fui lavar-me e aprontei o altar. Pauquet, ainda deitado, informou-me que sua missa seria às seis e meia. De mais a mais, que não fizesse muito barulho, que os rapazes queriam dormir. Vou até a barraca e começo o breviário. O rapaz do leite apresentou-se pontualmente e chamou-me para receber o leite. Finalmente Pauquet saiu da toca para providenciar um ajudante de missa para mim. Reis e Zanini ajudaram-me a missa.

Depois, recolho-me à minha barraca e termino o breviário. O chocolate está muito bom. Ocupo a manhã toda para acondicionar as plantas coletadas nos últimos dias. Uma parte já está praticamente seca. Nesse sentido disponho do melhor tempo possível. De qualquer forma preferia que chovesse mais e que o sol não fosse tão quente. Poderia secar as plantas junto ao fogo. Carlos Roberto Cirne Lima faz-me companhia quase o tempo todo. É um rapaz magnífico, discreto, de uma disposição fora do comum e jeitoso.

Depois do almoço subo ao longo do rio acompanhado por Carlos Roberto a fim de localizar o ponto onde Rüdiger encontrou o fragmento da couraça do Gliptodonte. Depois de mais ou menos uma hora de marcha chegamos ao local onde o rio acumulou em alguns lugares camadas de até dez metros de argila. As camadas superiores são escuras, as camadas inferiores amarelo-avermelhadas até inteiramente brancas. Julgo que essa parede de argila formou-se, pelo menos em parte, durante o Quaternário. Vasculhamos durante uma hora inteira toda a região, sem encontrar o menor vestígio de algum fóssil. Alimentava a melhor das esperanças de topar não apenas com um fragmento, mas com um esqueleto completo, mas as minhas expectativas foram frustradas. Uma coisa, porém, é certa. Ocorrem aqui sedimentos quaternários que até agora não tinham sido observados nesta região. $\mathrm{O}$ osso fossilizado que o Dr. Aldo afirma que um conhecido teria encontrado no Garupá, aponta para a mesma direção. Trata-se, provavelmente, de um osso de Magatério ou Mastodonte.

Os peixes brincavam na água clara e morna. Concentravam-se em cardumes no local onde a correnteza era mais forte, à espera de um petisco que o acaso lhes levaria diretamente para a boca. Num remanso, dois grandes peixes descansavam juntos. Um deles mandou-se, fazendo barulho, e o outro permaneceu no local. Carlos pegou minha faca e tentou abatê-lo. Errou e o peixe abalou-se para um outro remanso. Peguei a faca e esgueirei-me até lá. Com a certeza de que pegaria o peixe apliquei um violento golpe. Devo ter golpeado com a faca inclinada, de maneira que ela foi desviada e terminou no barranco. O peixe desapareceu num poço profundo. Cansados e chateados, voltamos para o acampamento.

Chegamos exatamente na hora do café. Depois andei por mais duas horas pelo campo encostado no mato colecionando artefatos de pedra. À tarde, o Zanini por um nada tocou fogo no mato. Por causa de uma brincadeira sua alastrou-se o fogo a partir do campo em direção à beira do mato, dominado pela pronta mobilização de todo o grupo.

$\mathrm{Na}$ hora do almoço ouviram-se algumas palavras em alemão. Laux meteu-se e disse que éramos brasileiros e não alemães. Carlos 
Roberto interrompeu que falar duas línguas era mais do que uma. Laux emendou saber, sim, mas falar não. Agora sei quem é esse moço. Sua mãe é alemã e não para de vociferar contra os ingleses e americanos. Ficou claro que também dos alemães não quer saber nada. Com esse tipo de gente não dá para conversar. Somos a escória do mundo e no momento em que nos tornamos traidores da nossa língua e maneira de ser, somos os tais. Mas esperem um pouco, senhores! É possível que venha o dia em que a lança se volta ao contrário. Se isso acontecer trataremos os senhores exatamente da mesma forma como nos ensinaram. Não leva a nada agir com arrogância e miudeza. A vida é bem diferente. Ou pisoteio ou sou pisoteado.

Essas reflexões convencem-me cada vez mais de que a vida, a luta real pela vida entre os homens, acontece a partir de princípios bem diferentes daqueles que os livros piedosos nos pintam. Na insistência em inculcar a humildade e a submissão esconde-se uma considerável parcela de autoritarismo. O mesmo se pode afirmar de certas formas de piedade e devoção. Demais vezes a ascese serve apenas para garantir lucros demasiadamente miúdos e mundanos. Observei isso, de modo especial, no Pe. Hofer ${ }^{79}$. Tentou, pelos mais diversos argumentos ascéticos, convencer-me a renegar a minha língua e minha maneira de ser, para que eu "rezasse" de acordo com a sua cartilha, como falou para outros. Trabalho pela Igreja não somente por motivos religiosos. Afirmou que eu não deveria atribuir a uma proteção especial de Deus que meu sermão em alemão na Linha Imperial não teve conseqüências e outras coisas mais. Todos esses empenhos fizeram crescer em mim a convicção de que o homem tem necessidade de impor-se de alguma maneira. Ninguém tem

79 Natural da Suíça, o Pe. Walter Hofer era o Superior Provincial naquele período. O relacionamento de Rambo com esse superior não era pacífico, sobretudo por divergências em relação à Campanha de Nacionalização promovida pelo Estado Novo e há pouco encerrada, com o término da ditadura de Vargas (ABR). acesso ao santuário mais íntimo da minha alma. A minha consciência cabe-me abrir ao sacerdote como representante de Deus, para receber o perdão dos pecados. De resto não estou obrigado, sob pretexto algum, a abrir-me com quem quer que seja. De forma alguma permito vasculhar a vida da minha alma. E que proveito poderia ter? Conheço suficientemente a minha fé para estar em condições de dar conta da minha vida religiosa. Não acredito que o diretor espiritual tenha capacidade de avaliar as coisas melhor do que eu mesmo. Por que razão, então, cruzar a porta desses senhores, quando eu mesmo estou em condições de dar conta do recado? Se eu mesmo não tenho como resolver, muito menos um terceiro.

Em outras palavras. Exijo liberdade, total liberdade, sem intermediários entre mim e Deus. Não queiram me tirar a pouca liberdade de que disponho. Só há uma instância que tem autoridade sobre mim: a Igreja. Portanto, liberdade na maneira de praticar e viver a religiosidade, liberdade na maneira de conceber meu povo, minha maneira de ser e minha língua. Liberdade no pensar e no agir, até o limite que a obediência o permite. Mas essa regulamentação, de qualquer forma, só pode dizer respeito ao lado externo da minha vida.

\subsubsection{5 - quinta-feira}

Esta noite dormi bem. $\mathrm{O}$ despertador tocou às quatro e meia. Levantei e fui lavar-me no rio e preparei o altar. Entretanto passou das cinco. Acordei o Rüdiger e Pauquet. Pauquet tirou os rapazes das barracas. Às cinco horas e dez minutos foi possível começar a missa. Os rapazes assistiram a primeira missa.

Depois da missa, rezei o breviário. Pauquet tinha planejado sair já às seis horas. Acontece, entretanto, o que eu havia previsto. O café prolongou-se a tal ponto que apenas perto da sete horas nos reunimos junto à cascata. $\mathrm{O}$ capataz já nos esperava. Deixara o cavalo preso no outro lado. Um bando inteiro de cachorros veio correndo. Todo o bando atirou-se na água e começou a lutar pelo pedaço de madeira. Depois 
saíram e sacudiram-se do rabo à cabeça, com tal violência que a cabeça parecia voar numa direção e o rabo na outra. Ficou sete horas até que finalmente nos pusemos a marchar. No meio do capim encontramos três ovos de avestruz. Um pouco adiante mais um. Depois de uma hora de marcha os cachorros levantaram uma lebre. $\mathrm{Na}$ fuga desesperada a infeliz esbarrou com uma cerca de arame farpado e foi pega. Há muitos cachorros. O capataz cortou com um golpe de facão os quartos traseiros e deixou o resto para trás.

A marcha prolongou-se pelo campo. Os pés doíam-me. Quase não há perspectiva de encontrar espécies de plantas. De qualquer maneira encontrei a Quilaia ${ }^{80}$, embora em condições precárias.

$\mathrm{O}$ Pe. Pauquet tem uma perna em más condições. O capataz cedeu-lhe o cavalo. Pauquet montou e cavalgou na frente. Todo o cortejo dava uma impressão trágico-cômica. Lembreime da retirada de Napoleão da Rússia. O Senhor derrotou-o com homens, carroças e cavalos. Só faltou o granadeiro para gritar uma maldição na beira da estrada. Perto de um valo os cachorros desentocaram um jovem tatu e o apanharam. Os rapazes o levaram para assar. A marcha continuava cada vez mais monótona pelo campo. O sol queima impiedoso sobre o lombo. Penetramos num mato de espinheiros ${ }^{81}$. Mais adiante uma galeria de mato mais alto anunciava a presença do rio.

O capataz prendeu o cavalo e entrou conosco no mato. Parece-se muito com a mata virgem. Chegamos ao rio identificado como Quarai Mirim. Abaixo do calor arrastamo-nos pelo barranco do rio, até o ponto em que o vale se torna mais largo e o Quarai Mirim desemboca no

${ }_{80}$ Quillaja brasiliensis (A. St.-Hil. \& Tul.) Mart., da família Quillajaceae, conhecida, popularmente, como paude-sabão, árvore-de-sabão ou sabão-de-soldado (JNCM).

81 Mato de espinilhos (Vachellia caven, Fabaceae); o mesmo que espinillal, em castelhano (JNCM).
Quarai ${ }^{82}$. O local apresenta uma vegetação tão densa que fica fácil ultrapassá-lo.

Havia uma canoa no barranco. Admirei-me quando o pequeno Zanini e Carlos perguntaram em tom incisivo de quem era a canoa e se era permitido pescar. Um homem de cara fechada, uma mulher magra, três ou quatro crianças e um grande número de cachorros rodeavam a canoa. Um cachorrinho estava deitado sobre um travesseiro dentro da canoa. A canoa afastou-se do barranco, mas os cachorros preferiram nadar ao lado. Mais abaixo, num lugar raso, o homem, a mulher e o rapaz maior saltaram para dentro da água e arrastaram a canoa. Refleti comigo. Essas pessoas são mais ricas na sua pobreza do que o Dr. Aldo com seus dois filhos e a discórdia na família.

O capataz e o Rüdiger foram preparar o churrasco. Deitei-me de costas no mato. Há aqui uma magnífica clareira. As árvores são altas, o chão limpo. Os muitos ossos espalhados pelo chão falam de não poucas excursões. Dormito um pouco. Depois vou junto ao fogo e tomo um chimarrão. O capataz contou que fazia quase dois anos que estava aqui. Já ganhara um bom dinheiro, mas a doença da mulher levara tudo. Apesar de tudo falecera. $\mathrm{O}$ tom singelo com que contou a história permite adivinhar um coração bom. Também este homem que empatou todo o seu dinheiro no tratamento da mulher é mais feliz que o Dr. Aldo, com todo o seu dinheiro e suas discórdias.

Faço uma caminhada. Uma companhia inteira anda sobre tábuas no rio. A água não passa da largura de três metros, trinta centímetros de profundidade, mas apertada entre os barrancos. Os rapazes estão deitados no rio, como porcos do mato e, no meio deles, o Pe. Pauquet, parecendo um hipopótamo. Passo o rio sem tirar os sapatos $^{83}$. É a primeira vez que me encontro no

82 A foz do Quaraí Mirim (30 $14^{\prime} 59.54^{\prime \prime}$ S e $56^{\circ} 37^{\prime} 29.86^{\prime \prime}$ O) fica cerca de $8,6 \mathrm{~km}$ a oeste do acampameento, em linha reta (JNCM).

83 Relativamente grande, comparado a seu afluente Quaraí Mirim, o rio Quaraí corre em leito de pedras basálticas na maior parte de seu curso, permitindo fácil passagem 
Uruguai $^{84}$. Parece ridículo que esse riozinho miserável divida dois países. Não há vestígio de guardas de fronteira. O povo passa constantemente de uma margem do rio para a outra. Coleto no outro lado apenas uma planta, o "chifre do diabo" 85 . Volto e encontro o churrasco assando no espeto, o tatu ao lado. O capataz serviu-me um pedaço bastante gordo. Lambuzome de alto a baixo com gordura. Quando quis avançar no segundo pedaço não havia mais quase nada no espeto. Tenho que desistir. Pego minha bolsa e ponho-me no caminho de volta. Encontro um belo caminho ladeando o rio. Depois de algum tempo percebo que estou voltando para o acampamento. Saio de novo, procuro o mato de espinheiros e oriento-me na direção do Jarau. No campo, praticamente não havia nada para colecionar. Continuei imerso nas minhas reflexões.

Ainda uma vez reflito sobre o problema da liberdade. Tenho a convicção de que, quanto mais e quanto mais profundamente reflito sobre essas coisas, tanto mais me aproximo da solução. Confesso que, nessa questão, amadureci e tornei-me livre por dentro. Constatei que, exatamente nesse ponto, a autoridade não dá em nada. O meu próprio eu é-me muito mais precioso do que todo um discurso sobre autoridade é capaz de transmitir. Cada indivíduo é uma imagem única de Deus na sua manifestação da capacidade de o imitar na sua trajetória temporal. Qualquer massificação vem do mal. Ninguém tem autorização de se imiscuir no santuário mais íntimo da minha fé e da minha vida, a não ser que Deus o ordene por meio dos seus representantes infalíveis. Nem neste caso vale uma opinião ou uma maneira de ver. Também neste caso exijo vinho puro, pois entram em questão ver-

de uma margem à outra em muitos pontos nos períodos de estiagem, caso do verão de 1945 (JNCM).

${ }^{84}$ Confusão de Balduíno Rambo. Na viagem de 1941 ao sudoeste do Estado, ele já havia coletado plantas nos arredores de Rivera, Uruguai (JNCM).

85 Ibicella lutea (Lindl.) Van Eselt. (Pedaliaceae), espécie também conhecida, popularmente, como "chifrede-veado" (JNCM). dades que fazem parte da própria natureza da fé.

Os cavalos mostram um grande interesse por mim. Logo que me perceberam reuniram-se, sopraram pelas narinas, chamaram os demais e trotaram em círculo em minha volta. Fiquei parado, deixei que se aproximassem e saudei-os amigavelmente. $\mathrm{O}$ bando inteiro saiu abalando. Foi esquisito como uma pequena égua barriguda passou pelo mato de espinheiros. Depois de algum tempo aproximou-se sozinha de mim. A estranha companhia acompanhou-me durante bem uma hora. $\mathrm{O}$ gado vacum lançou mão de uma outra tática. Eu estava coletando plantas num lugar livre. De súbito escutei atrás de mim um leve ruído. Ergui-me. Menos de dois metros estava toda a companhia malhada. Como que soprados pelo vento saíram correndo. Reuniramse de novo e seguiram-me por mais um bom tempo.

No campo não havia muito a ser colhido. Apesar de toda a atenção não encontrei um segundo exemplar de Quilaia.

Chegado ao local dos instrumentos de pedra interessei-me por eles. Topei com um lugar onde pontas em boas condições são freqüentes. Enchi um dos bolsos da calça e fui para casa. Eram cinco horas quando passei pelo arroio ${ }^{86}$. Sentia uma terrível sede e uma fome de cão. Tomei uma quantidade enorme de água, depois peguei um punhado de bolachas. Fui até o local onde estava o peão que cuidara do acampamento durante o dia. Cuidava de um quarto de ovelha sobre o fogo. Cortei um pedaço e tomei um gole de vinho e minhas energias estavam restabelecidas.

Fui tomar um banho rápido, pois a água estava muito morna. Volto para a barraca e rezo o breviário.

O filho do capataz vem com um balaio cheio de pão e leite para preparar o chocolate. Sentou-se comigo e conversamos por um tempo. Contou que a mãe falecera nove anos antes. Uma irmã encontrava-se em Quaraí e uma segunda

86 Balduíno Rambo refere-se à sanga Nhanduvaí (JNCM). 
em Rosário. No mês que vem faria quinze anos e pretendia passar um ano em Quaraí para freqüentar a escola.

Escrevo no diário e escuto a algazarra dos rapazes aproximando-se. Chegaram os primeiros, suados, sujos, com sede e esfomeados. Deixam-se cair no chão, em cadeiras e na minha cama e bebem água como as abelhas. Finalmente chegou Pauquet bufando. Saíram às três e meia para chegar às sete.

À noite é servido um gostoso leite com chocolate e pão. $\mathrm{O}$ calor tinha sido muito forte, mas os rapazes estão bem dispostos. O dia valeu a pena.

\subsubsection{5 - Sexta-feira}

Apesar do grande calor, dormi bem esta noite. A manhã estava amena. Levantei às cinco $\mathrm{e}$ meia e fui lavar-me e rezei todo o breviário. Depois tirei Pauquet e Laux da toca. Pauquet ficou deitado até o fim da missa. Depois da missa tomei duas xícaras de leite, comi alguns biscoitos e fui para o outro lado do arroio. Propus-me explorar para valer o local que ontem tinha encontrado. Encontrei apenas vestígios precários. Procurei até pelas dez horas por todo o campo e coletei uma única planta. Fui para casa. O calor estava muito grande.

Pus-me a ordenar e acondicionar para valer as plantas. Ocupo-me com isso até às quatro horas da tarde. Passo então para as pedras. O trabalho rende melhor. Separo os melhores exemplares que no fim somam um bom número. Creio que o material de que disponho, em sua grande maioria, é de pontas de flecha, instrumentos de golpear, de raspar, de afiar, de fincar. Tenho a impressão de que se trata aqui de um caso único no Brasil. À noite vou tomar banho. Pauquet organiza uma diversão na água e cabo de guerra. Protagoniza com isso uma enorme algazarra. Trato de mandar-me. Não suporto esse tipo de métodos de educação.

\subsubsection{5 - Sábado}

A noite que passou foi muito quente. Apesar disso dormi bastante bem. Rezo todo o breviário antes da missa. Pelas nove horas saio com João Alfort à procura de fósseis. O calor é insuportável. Descemos pelo mato, pela margem esquerda do rio. Num valo seco encontramos dois zorrilhos. Os dois porcalhões prepararam com certeza uma carga fedorenta para nos aplicar. Mas João Carlos sabe como lidar com eles. Cutucou com uma vara as costas explicando que por algum tempo ficam mansos e se esquecem da sua arte. Os pequenos fedorentos mostraramse bem mansos e juntos e bem comportados aceitaram comida. João Carlos comentou que era uma felicidade que a mãe não andava por perto. Seria aquela recepção. Ela não permite que os filhotes saiam da toca antes de saberem disparar. Defende os filhotes com grande valentia.

Aproximamo-nos do rio. João Carlos constata que eu e Cirne Lima não tínhamos ido longe o suficiente rio abaixo. Descemos pela margem até a ilha que fecha o curso do rio. Mal tínhamos chegado e João Carlos chamou para anunciar que tinha encontrado um escudo. De fato encontrou um, mas as partes não ficavam unidas. Pode ser um sinal de que nas imediações encontra-se o local original da deposição. Com isso um bom desfecho coroou a nossa saída.

Depois do meio dia empacotei em primeiro lugar as plantas. Couberam todas na mala grande. Para as demais bagagens o Pe. Pauquet pôs uma caixa à minha disposição. Coube tudo, mas ficou muito pesada. À tarde resolvi finalmente me barbear depois de quase duas semanas. Depois fui colecionar pedras durante uma hora. Encontrei, ainda, um bom número de boas peças.

À noite aparece o Dr. Aldo. Presenteia-me com um pacotinho de charutos, já que os meus tinham terminado. Conversei com ele um bom tempo. Pretende enviar-me fósseis que ele espera encontrar por aqui.

Às nove horas da noite acontece o fogo de despedida. As chamas da fogueira fazem um efeito magnífico no meio do mato. Os versos oferecidos pelos rapazes não são ruins. O melhor papel fez Reis, o solitário. 
Os rapazes já desmontaram todas as barracas, menos três, e dormem ao relento. Pelas dez horas cessa a algazarra e eu durmo magnificamente.

\section{REFERÊNCIAS BIBLIOGRÁFICAS}

ALVES, F. da S. Fitogeografia da Região do Jarau -Quaraí (RS). 2012.101 p. Tese (Doutorado em Engenharia Florestal) - Universidade Federal de Santa Maria, Santa Maria, 2012.

ALVES, F. da S.; MARCHIORI, J.N.C. Nota sobre a ocorrência natural do butiá-anão (Butia lallemantii Deble \& Marchiori) no Cerro do Jarau, Quaraí - Rio Grande do Sul. Balduinia, Santa Maria, n. 24, p. 30-32, 2010.

AZARA, F. de. De los índios salvajes. In: Los indios del Plata. Montevideo: Editorial ARCA, 1968. Enciclopedia Uruguaya, n. 1, p. 83.

BURKART, A. Leguminosas nuevas o criticas. Darwiniana, San Isidro, v. 7, n. 2, p. 216-239, 1946.
FURTADO, N.F. Vocábulos indígenas na Geografia do Rio Grande do Sul. Porto Alegre: Pontifícia Universidade Católica do Rio Grande do Sul, 1969. 193 p.

MARÇAL, J.B. Quaraí, terra de intelectuais e de guerreiros. Porto Alegre: s/ref., 1995. p. 67.

MARCHIORI, J.N.C.; ALVES, F. da S. O inhanduvá (Prosopis affinis Spreng.) no Rio Grande do Sul. 1 - Embasamento fitogeográfico e pendências terminológicas. Balduinia, Santa Maria, n. 24, p. 1-11, 2010.

RAMBO, A.B. Viagem de Balduíno Rambo ao sudoeste do Rio Grande do Sul no ano de 1941. Balduinia, Santa Maria, n. 36, p. 13-29, 2012.

RAMBO, B. Leguminosae Riograndenses. Pesquisas, Botânica, São Leopoldo, n. 23, p. 1166, 1966 (separata).

RUBERT, A. A Diocese de Santa Maria. Santa Maria: s/ref., 1957. p. 198.

TESCHAUER, C. Avifauna e flora nos costumes, superstições e lendas brasileiras e americanas. Porto Alegre: Livraria do Globo, 1925. 280 p. 